Revista Iberoamericana, Vol. LXXXV, Núm. 267, Abril-Junio 2019, 425-453

\title{
"ILUMINANDO A DURAS PENAS": FORMAS DE VISUALIDAD MODERNA EN LA REVISTA URUGUAYO-ARGENTINA CARAS Y CARETAS ENTRE 1890 Y 1910
}

\author{
POR \\ Luis Rebaza-Soraluz \\ King's College, University of London
}

En una nota publicada en junio de 1895 en la Lippincott's Monthly Magazine, el estadounidense Sidney Fairfield hace una aguda crítica a los editores que en esos años siguen lo que él denomina "tendencias modernas" a la hora de preferir una pieza literaria en lugar de otra. El título de su texto, "The Tyranny of the Pictorial", evidente no solo la posición opresiva ocupada por lo visual a fines del siglo XIX, sino también el hecho de que tal dominio es ejercido en un campo que debe serle ajeno: el de la escritura impresa. Los criterios que se vuelven cada vez más importantes son la brevedad y, sobre todo, la "ilustrabilidad":

El editor de un prominente semanario dice que su periódico no quiere ningún material literario que pase de cierta breve extensión-que llene aproximadamente tres columnas. Lo que él quiere y se esfuerza al máximo por conseguir son ilustraciones; el material de lectura que las acompañe es muy fácil de obtener, probablemente sin necesidad de pedir ayuda exterior. En otras palabras, el puro elemento gráfico es el fin último y único de este empresarial editor. (861)

En apenas dos décadas, afirma Fairfield, la presencia de la imagen visual en el contexto de la palabra impresa no solo se ha incrementado sino que ha producido tanto un cambio extremo en la naturaleza de las revistas literarias como la aparición de un nuevo tipo de editor (asesor textual y, en parte, marchand), además de la inclusión obligada del fotograbado de semitono. Para Fairfield, el impacto mayor está en el desafío planteado al poder de la palabra escrita, entendida esta como "la primera y más alta expresión del pensamiento" (864); es decir, la amenaza inminente de que un tipo de orden no verbal domine la producción de significado. En el mundo moderno,

\footnotetext{
El término pictorial debe entenderse como "lo gráfico" más que como aquello de "calidad pictórica". Todos los textos publicados originalmente en inglés que se cita en estas páginas, al menos que se indique expresamente, han sido traducidos por L. R. S.
} 
el valor de un texto ya no está determinado por el haber, o no, conseguido dar forma verbal a lo que Fairfield llama "la verdad más profunda" sino por lo que se coloca frente a los ojos.

Menos de una década más tarde, también en los Estados Unidos, en el ensayo "The Reign of the Spectacular", ${ }^{2}$ publicado en 1903 en The Dial, Annie Russell Marble confirma la irreversibilidad de ese cambio: "En las diferentes fases de la actividad y el pensamiento moderno, lo evidente mantiene un dominio sin oposición" (297). Su nota agrega dos aspectos nuevos; primero, que en la manera moderna de adquirir conocimiento la visión ha desplazado las otras facultades: "Los hechos que son llamativos, las ideas que son chabacanas, la literatura en episodios y gráfica, ganan el favor popular. El ojo es de los sentidos el monarca, frecuentemente un substituto del oído, de la imaginación y de la razón. Las impresiones superficiales satisfacen; 'los ojos de nuestro entendimiento' resultan iluminados [enlightened] a duras penas"; y, segundo, que el predominio de la representación visual en detrimento de la representación verbal ha invadido también los predios de la palabra hablada: "Pueda que oradores de renombre todavía sean capaces de encontrar oyentes para un discurso acerca de cierto tema científico o literario, pero incluso ellos se ven ocasionalmente sorprendidos por la pregunta ‘¿No tiene ninguna conferencia que esté acompañada con diapositivas?’”.

La crisis epistemológico-cultural provocada por la modernidad, de la manera en que la describen estos autores en los Estados Unidos, es también un hecho en la Sudamérica de entonces. Una caricatura a doble página publicada en 1895 con el título Las verdades del ministro [Fig. 1] durante el periodo uruguayo de la revista Caras

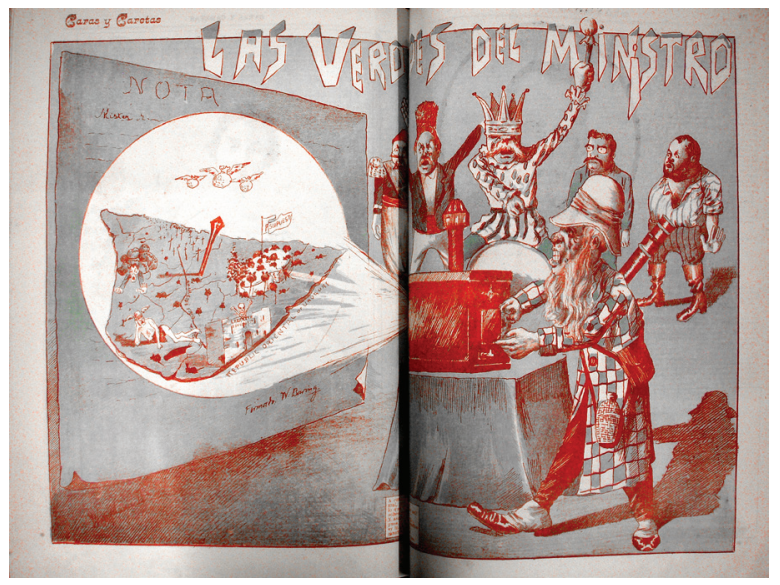

Figura 1

2 En este caso, por spectacular debe entenderse lo "evidente"; es decir, lo que está frente a los ojos, o se aparece a la visión.

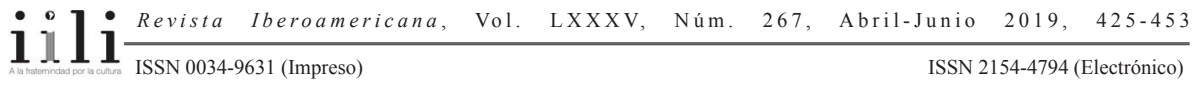


y Caretas, lo demuestra de manera contemporánea al texto de Fairfield. La imagen presenta el momento en el que los contenidos de un reporte socioeconómico sobre la situación del país, escrito por Walter Baring, Ministro y Cónsul General Británico en Montevideo, se transforman en verdades evidentes al convertirse en imágenes gráficas de una diapositiva que hace visible la corrupción política del gobierno de Juan Idiarte Borda. Menos de una década más tarde, esta vez en la Caras y Caretas del periodo argentino, en 1902 y 1903, aparecen respectivamente dos imágenes que son contemporáneamente cercanas al texto de Russell Marble: la primera es una caricatura y la segunda un fotograbado; ambas representan al renombrado intelectual Alberto Martínez acompañando con "proyecciones luminosas" una conferencia sobre la arquitectura romana [Fig. 2] que, en palabras de Russell Marble, estarían iluminando “a duras penas los ojos del entendimiento" del público de Buenos Aires.
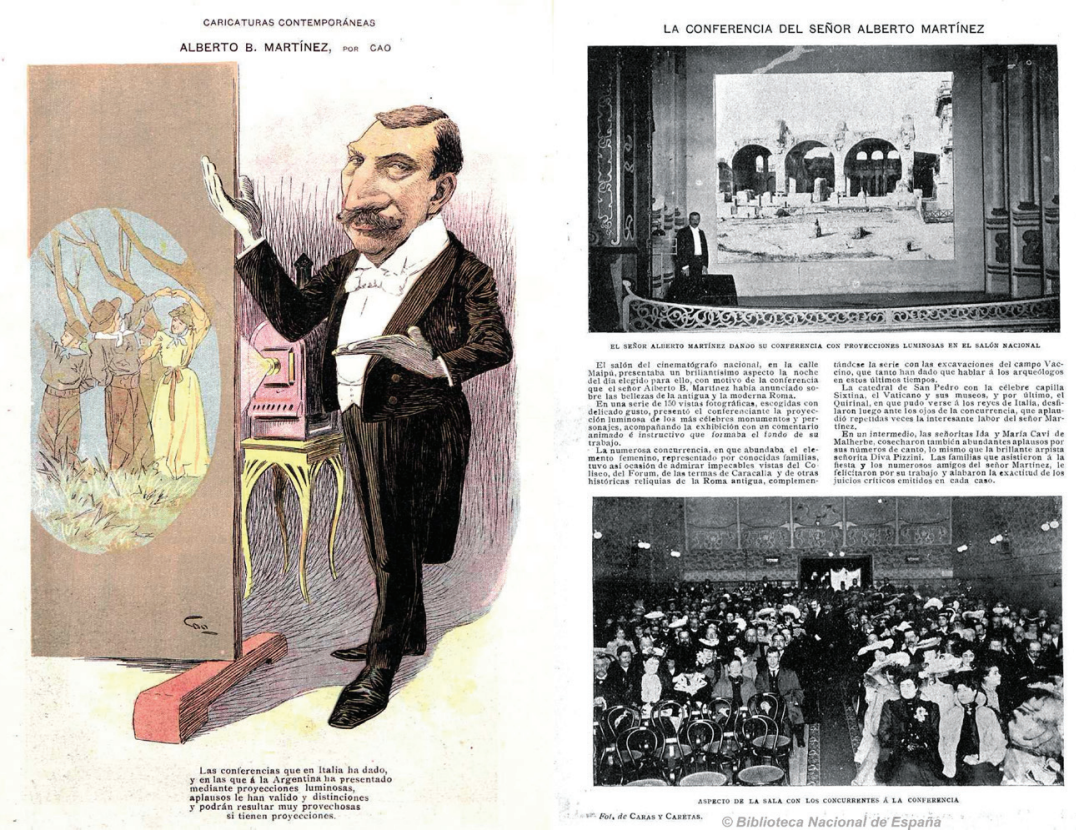

Figura 2. Cortesía: Biblioteca Nacional de España

El ensayo de Fairfield despliega un escenario complejo en el cual la experiencia de la sociedad de masas va tomando forma mediante el lenguaje verbal, la visualización y el contacto directo e indirecto con las tecnologías que les son afines. Presenta además un conflicto entre la escritura y las ilustraciones asociándolo a ideas de buena

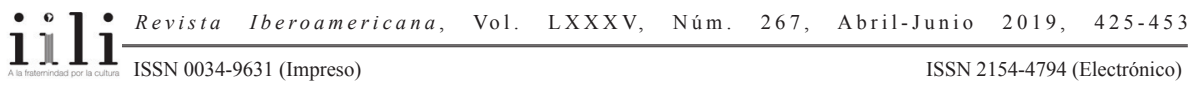


y mala literatura. Las imágenes visuales, sin embargo, no necesariamente degradan "el pensamiento" o "la verdad" pues muchas de ellas son ciertamente complejas y de múltiples estratos; cuestionan, sí, la hegemonía de la palabra.

El trabajo que presento en estas páginas busca articular la visualidad, entendida como construcción social de la visión, con el tipo de conocimiento contemporáneo al que se refieren los críticos de la prensa gráfica; es decir, relacionar las diferentes maneras de ver presentes en Caras y Caretas con el telón de fondo que constituye la consolidación de la política democrática, la formación de la opinión pública moderna, el surgimiento de las clases medias y el horizonte de un futuro progresivo. Mi ensayo parte de estos fenómenos y de la manera en que sus procesos son documentados por Caras y Caretas (Uruguay 1890-1896; Argentina 1898-1941) en la región del Río de la Plata entre 1890 y 1910. El primer objetivo de mi ensayo es mostrar en el contexto de Caras y Caretas la manera en que el dominio de lo visual reúne incómodamente más de una manera de ver, más de una "subcultura visual", como llama Martin Jay (4) a los diferentes regímenes escópicos que coexisten en la modernidad; me enfoco en particular en tres: la manera que Henry Miller ha denominado political likeness -que traduzco como "representación política de la semejanza"-, la que defino como "desvelamiento fantasmagórico ilustracionista" y, de una forma muy general, lo que voy a llamar "representación fotomecánica".

El texto de Fairfield que he citado al inicio de este estudio llama también la atención sobre otros encuentros visuales difíciles, tales como el de la presentación no comercial de ideas (tratados aburridos) versus la información fácil de consumir que puede ser aprehendida de un vistazo. Por sobre estos aspectos, su reflexión revela un cambio paulatino que convierte las publicaciones periódicas en entes gráficos y textualmente más ligeros y da lugar al fenómeno de la "Revista Popular Ilustrada". El segundo objetivo de mi ensayo es discutir hasta qué punto este último producto, y los niveles de complejidad gráfica de sus imágenes en competencia y colaboración con el lenguaje verbal, constituye la tecnología de una nueva manera de ver, de una nueva subcultura visual a finales del siglo XIX.

Diferenciándose del crítico anterior, Russell Marble describe lo que parece ser el resultado de una doble lucha cultural; por un lado, critica la hegemonía de la visión que se impone por sobre la variada representación sensorial y, por el otro, la autoridad de lo empírico que se consolida sobre los otros procesos cognitivos. Además de explorar en Caras y Caretas el creciente papel de la visión como substituto de los otros sentidos y la lucha contemporánea entre empirismo y racionalismo, el tercer objetivo de mi ensayo es discutir en la revista algunas consecuencias culturales del enfrentamiento entre el dibujo y el fotograbado, la creación de un público de clase media en un plan de nacionalismo progresivo y la difusión de temas finiseculares como la criminología, la frenología y el espiritismo, entre otros. La importancia que tiene Caras y Caretas

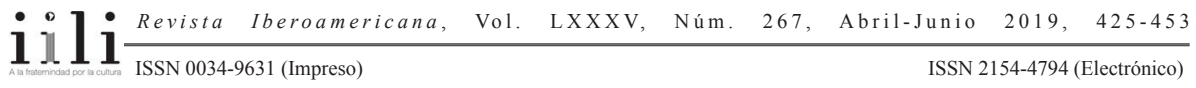


para un acercamiento como el que propongo reside en que esta publicación muestra casi semana tras semana el proceso de formación de la revista ilustrada (y de la opinión pública y la política modernas) como parte intrínseca de la experiencia urbana moderna en Hispanoamérica.

Como la define Miller, la "representación política de la semejanza" es una manera de ver que domina la visualización de la esfera pública en la Gran Bretaña del siglo XIX (225). Hace visible el sistema político a través de dos tecnologías principales: el retrato y la caricatura impresa (4-5). Su popularidad, afirma Miller, se debe a las siguientes razones:

Primero, se pudo crear narrativas e historias nacionales a través de los retratos de grandes políticos y hombres de estado que marcaron hitos. Segundo, el retrato fue un elemento crucial en la formación y reafirmación de las identificaciones políticas. Tercero, la proliferación de la representación política de la semejanza reflejó una demanda por ver y escrutar los rostros de aquellos que aspiraban al liderazgo político, sea en el Parlamento o fuera de él. Cuarto, al familiarizar las audiencias local y nacional con la representación de la semejanza, los retratos y las caricaturas se hicieron factores importantes en la formación, tanto individual como colectivamente, de la imagen pública y la reputación de los políticos. (9)

Los editores de una publicación como la Caras y Caretas uruguaya crean narrativas, agrupan simpatías y antipatías, identifican y hacen familiares los rasgos de determinadas personas, y semanalmente dan prestigio y desprestigian a políticos y personajes públicos de sectores como el ejército, la iglesia o la propia prensa. Sus periodistas y dibujantes hacen reconocimientos en los retratos y atacan integridades en las escenas satíricas. Si bien el retrato impreso guarda fuertes vínculos con la pintura, entre este género y las representaciones litográficas de semejanza existen diferencias marcadas por la modernidad; así lo identifica Charles Baudelaire en su ensayo "El pintor de la vida moderna", de 1863, entre los que denomina elementos "eterno e invariable" y "relativo y circunstancial" de la belleza (69). El retrato pictórico ofrece trascendencia al estatus del sujeto al extraerlo rígidamente de su temporalidad (Miller 12), la representación litográfica de la semejanza convierte los contenidos tradicionales identitarios en continuas novedades producto de la dinámica social.

En un período en el que tanto Europa como Latinoamérica pasan por lo que Pablo Piccato ha llamado, para el caso de México, el "proceso de creación de una esfera pública moderna" que busca una correspondiente legitimidad política, la prensa crea y canaliza posiciones de lo que luego viene a llamarse "opinión pública" (346). Para el pensamiento de la época, la supervivencia de un régimen democrático se sostiene sobre

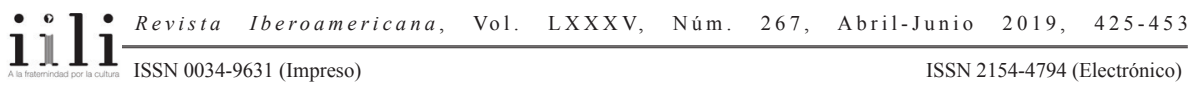


el poder de la opinión pública; ésta sería capaz de garantizar la estabilidad política de un país puesto que puede prevenir el descontento social haciendo que tanto el Congreso como la prensa representen de manera efectiva la soberanía popular a través del debate racional y honorable (331). Caras y Caretas y sus imágenes son partes constitutivas de este debate a la par que constructoras y canalizadoras de ciertas tendencias de opinión que atraen a determinados remanentes de la vieja aristocracia colonial, a sectores de la alta burguesía y la burguesía emergente, y a grupos de artesanos que están en desacuerdo con el status quo; entre ellos se encuentran muchos inmigrantes, como el fundador de la revista, el español Eustaquio Pellicer. Revistas satíricas de caricatura como ésta, en un período de afirmación republicana, reflejan lo que Richard Taws llama, para el caso de la producción gráfica de la Revolución Francesa (1789-1799), "la ambivalencia producida por los deseos intermitentes de reflejar tanto las ambiciones políticas y posición de clase de su público lector, como la voluntad de presentar un documento imparcial de los eventos" (36). Eso las hace selectivas en sus ataques de clase puesto que corren el riesgo de ofender a sus compradores.

La analogía entre la gráfica política de la Ilustración y la uruguaya del Fin de Siglo no es arbitraria. El impacto de la caricatura francesa revolucionaria en la Hispanoamérica finisecular ha sido estudiado por Fausta Gantús para el caso de México. Como ella bien señala, el público de la gráfica satírica en la prensa ilustrada está formado por quienes pueden votar y se encuentran al día con los eventos nacionales y locales, las posiciones de los partidos y de frentes políticos, las anécdotas personales de los hombres públicos e individuos notables, y los códigos de las llamadas alta y baja culturas (31). La expansión significativa del electorado traída por la modernización política liberal a lo largo del siglo XIX y, con esta, la subsecuente demanda de rendimiento de cuentas a los políticos, da lugar al establecimiento de un mercado significativo para la representación política de la semejanza; como ha señalado Miller para la Gran Bretaña, en la década de 1880 es ya un producto comercial a gran escala vinculado íntimamente a los adelantos tecnológicos de impresión. A pesar de que estos aparatos abaratan los costos notablemente, las revistas de caricaturas no son publicaciones para un mercado popular; entre sus compradores (que no son necesariamente sus únicos espectadores) se encuentran obreros calificados o pequeños comerciantes, pero las masas de trabajadores urbanos son con frecuencia representadas de manera negativa (Gantús 27). Hay sin embargo, en la tradición británica de los 1840s (Miller 34) y en la mexicana de los 1890s, ejemplos de publicaciones que, como ocurre en ilustraciones de José Guadalupe Posada, buscan ser identificadas como "populares" presentando conscientemente imperfecciones en el manejo de sus técnicas gráficas (Gretton).

Como ocurre con otras revistas populares contemporáneas latinoamericanas, Carasy Caretas también busca crear un sentimiento de comunidad capaz de congregar un público urbano (masculino y femenino) de valores liberales y estilo europeo de vida. Cubre

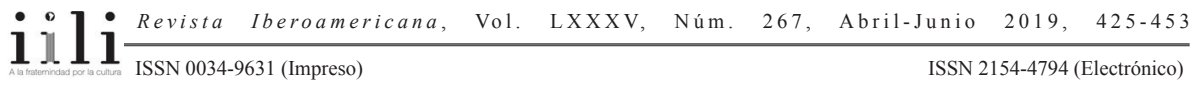


asuntos de actualidad y entretenimiento, pero su fuerte es, sin embargo, la caricatura de sátira política. Los compradores de Caras y Caretas reciben un producto que presenta la nación y lo político como procesos en marcha, y brinda la sensación de participar en el escrutinio de la esfera pública. Para asegurarse de la condición honorable de los miembros de su sistema político, la sociedad necesita fiscalizar su conducta y palabras. Periodistas y editores finiseculares como los de Caras y Caretas asumen el rol de fiscalizadores de la integridad. Los ilustradores llevan esto a cabo valiéndose de una gramática visual que, para hacer visibles los mundos interiores individual y colectivo, cuenta, por un lado, con las tradiciones iconográficas religiosas y oficiales; y, por el otro, con nuevos códigos visuales entre los que se encuentran saberes contemporáneos como la fisionomía, la frenología, el darwinismo social y la criminología antropométrica. A las reglas de esta gramática hay que sumarle el hecho de que, a lo largo del siglo XIX, la reproducción mecánica introduce nuevas relaciones paradigmáticas y sintagmáticas de jerarquía socio-económica y cultural como consecuencia de la producción serializada de sus productos. La importancia de un personaje o acción se mide así en el número de representaciones, su frecuencia, tamaño, lugar secuencial, y en qué tan prominentes son en comparación con otras. A esto se agrega su mercantilización por separado como imágenes aisladas o reagrupadas como parte de colecciones diversas (Miller 8). Se trata de hacer de estas imágenes periodísticas medios reveladores de "realidades profundas" difíciles de hacer evidentes con la escritura o el lenguaje verbal. Y aquí es donde la "representación política de la semejanza" finisecular entra en relación directa con el "desvelamiento fantasmagórico ilustracionista".

En el momento de su aparición, en julio de 1890, Caras y Caretas no es la primera publicación serializada de sátira política, literatura e ilustraciones que aparece en el país; la precede, por ejemplo, ¡Zapirón! (1861-1862). La Caras y Caretas del período uruguayo se autodefine como un "Semanario festivo" y combina en partes iguales imágenes litográficas de diverso tema y textos de calidad literaria. El material escrito se acomoda al modelo del nuevo periodismo estadounidense que pone mayor énfasis en los temas de actualidad y en un estilo más dinámico y directo; como Fairfield y Russell Marble describen, va desde la esfera de lo literario a la del reporte informativo y el lenguaje de la publicidad. Las imágenes que acompañan a estos textos pueden ser meramente ilustrativas, subordinadas, o tener valor editorial, ser coordinadas; no todas pueden considerarse superficiales. Tradicionalmente, retratos y caricaturas visualizan con éxito abstracciones que parecen encontrarse sobre todo en el campo del lenguaje verbal; mas, la palabra y la imagen comparten recursos como la alegoría. Durante el Fin de Siglo, afirma Miller, esta, centro simbólico de la caricatura política tradicional, es reemplazada por la representación de la semejanza. En esta relación entre la representación de la veracidad y la construcción de semejanza, que se encuentra en el centro de la construcción de la esfera pública en el siglo XIX, participa también

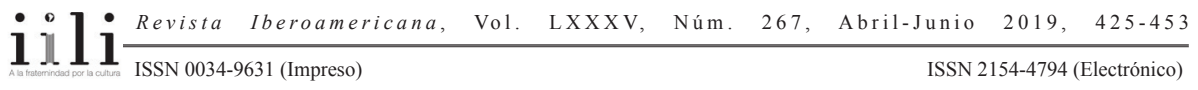


una tercera subcultura. Como Afirma Taws, la prensa gráfica, la impresión gráfica y la fotografía estaban envueltas en una "compleja relación de reciprocidad con las bellas artes" (36).

Los retratos litográficos que Caras y Caretas hace de miembros "notables" de la sociedad uruguaya y de personajes conocidos de la farándula tienen base fotomecánica, como pasa con muchas revistas ilustradas de la década de 1880 [Fig. 3]. Esto les permite ofrecer mayor semejanza con el retratado que la ofrecida por la pintura o el dibujo convencionales; la composición de estos retratos respeta, no obstante, casi todas las convenciones pictóricas, la más sobresaliente de las cuales es el gran control de la información visual ofrecida por la selección de escenografía, atributos, poses y gestos. Así como ocurre en los retratos pintados, las personas que posan en las fotografías son encarnaciones de estatus dentro de un contexto socioeconómico particular. El uso que Caras y Caretas hace de retratos y caricaturas con base fotomecánica no implica un acercamiento naïve o ingenuo a las fotografías o a su proceso de producción; no es tampoco su objetivo hacer uso de estas como un recurso para acercarse a la verdad. En el Uruguay de la época, así como en la Gran Bretaña (Miller 13), la caricatura es vista como una imagen de mayor veracidad que la fotografía. Cuando en el número 63 de la revista, publicado el 12 de mayo de 1895, los editores cambian el título de la serie de retratos de las portadas pasando del denotativo "Caricaturas contemporáneas" al irónico "Fotografías sin retoque" [Fig. 4], Caras y Caretas subraya cuál es la abstracción más

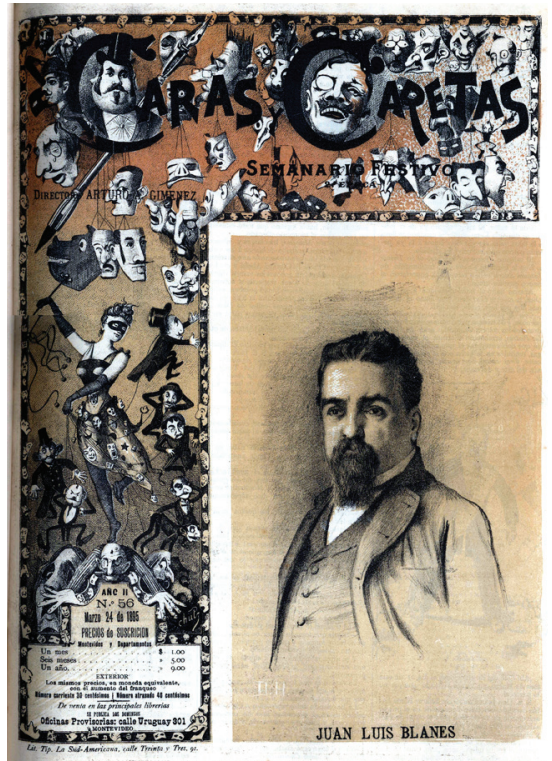

Figura 3

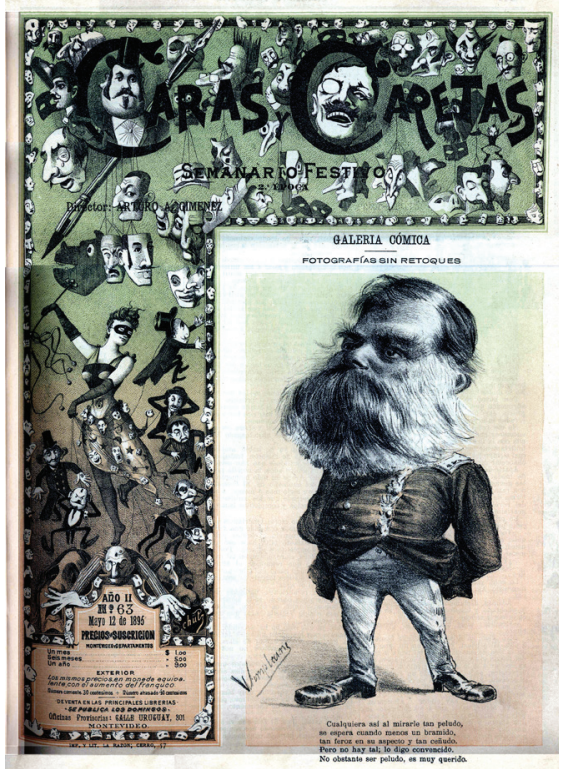

Figura 4

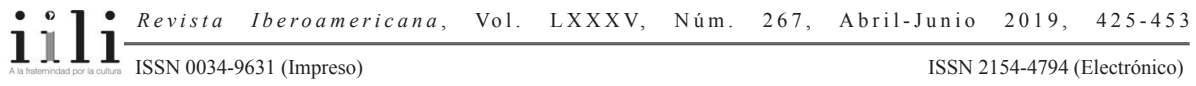


importante que desea visualizar: la transparencia de la esfera pública; y también qué medio es más efectivo para hacer ver la verdad: la caricatura. Esta habilidad altamente crítica del dibujo, y de las estructuras conceptuales de múltiples capas que lo acompañan, es un aspecto que las revistas del Fin de Siglo han recibido de las tradiciones gráficas que las preceden. La más significativa y difundida de estas es la reproducción en aguafuerte de caricaturas políticas durante los años de la Revolución francesa. Durante esta época también se popularizan las proyecciones de linterna mágica. Las dos tecnologías incluso se complementan. Es frecuente que las transparencias utilizadas por este aparato lleven impresas imágenes caricaturescas. Dentro de la caricatura, por otro lado, la presencia de linternas mágicas para ilustrar mensajes revolucionarios es una manera de hacer visible la iluminación racional y combatir en pos de lo que se entiende es la creación de una sociedad transparente sin falsedades ni engaños (Trévien 42). Lo que llamo "desvelamiento fantasmagórico ilustracionista" es una manera de ver procesos intelectuales y psicológicos que producen conmutaciones de un ente conocido a otro desconocido. Su tecnología es la linterna mágica. Como objeto visual, la caricatura de la revolución, afirma Richard Taws, ofrece una "respuesta politizada inmediata" y una "exageración precisa" (37). Según Claire Trévien, su tipo de lector-espectador es astuto, desconfiado de su sentido común y dispuesto a hacerse de los instrumentos necesarios para ver más allá de la realidad frente a sus ojos (46). Para algunos de ellos, los ilustradores de caricaturas son vistos como fuentes de "veracidad" (Taws 37). Caras $y$ Caretas no solo espera tener aquel tipo de lector-espectador frente a sus caricaturas, sino que además lo representa al interior de las imágenes.

En la litografía Las verdades del ministro, el tema de la verdad política en la esfera pública no es el asunto más importante para los fines de este ensayo, sino el que en su centro se presenta, explícitamente, el fenómeno de la dominación de lo verbal por lo visual. Valiéndose de una linterna mágica, quien parece ser Sir Edward Thornton ${ }^{3}$ proyecta, ante los ojos del presidente Idiarte Borda y de su Gabinete, la imagen de un reporte firmado por Walter Baring, Ministro y Cónsul General Británico en Montevideo, que presenta negativamente el manejo del país. Durante la proyección, las palabras de Baring se transforman en imagen presentando como verdad evidente aquello que es originalmente mera escritura. Esta transformación no es el producto de un espectáculo de efectos ópticos, sino la exposición formal mediante un instrumento científico manejado por un diplomático europeo. La posición del observador de este grabado podría ser equivalente a la de los sorprendidos miembros del gobierno uruguayo; mas, ese no es el lugar en que la revista lo coloca. El manejo del instrumento que se representa en

${ }^{3}$ El reporte está dirigido a la Corporación de Tenedores de Bonos Extranjeros con sede en Londres. Al publicarse el documento en junio de 1894, Thornton, ex Encargado de Negocios británico en el Uruguay, es miembro del Consejo de la Corporación y Presidente del Comité asignado al Uruguay.

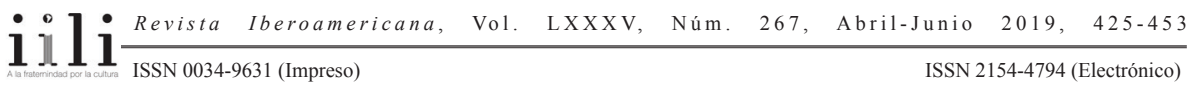


la litografía es una acción hecha análoga a los actos que está llevando a cabo quien observa y lee la imagen; esto coloca a Thornton y al lector-espectador en una posición similar y los convierte en observadores astutos entrenados por la Ilustración.

El mismo fenómeno se muestra en el aguafuerte francés revolucionario Lanterne magique republicaine montrée à sire Georges Dandin et à monsieur Pitt son féald ministre (c. 1794) [Fig. 5]. En esta imagen-que la litografía uruguaya parece reconstruir un siglo más tarde ${ }^{4}$ - un sans-culotte se sirve de una linterna mágica para proyectar

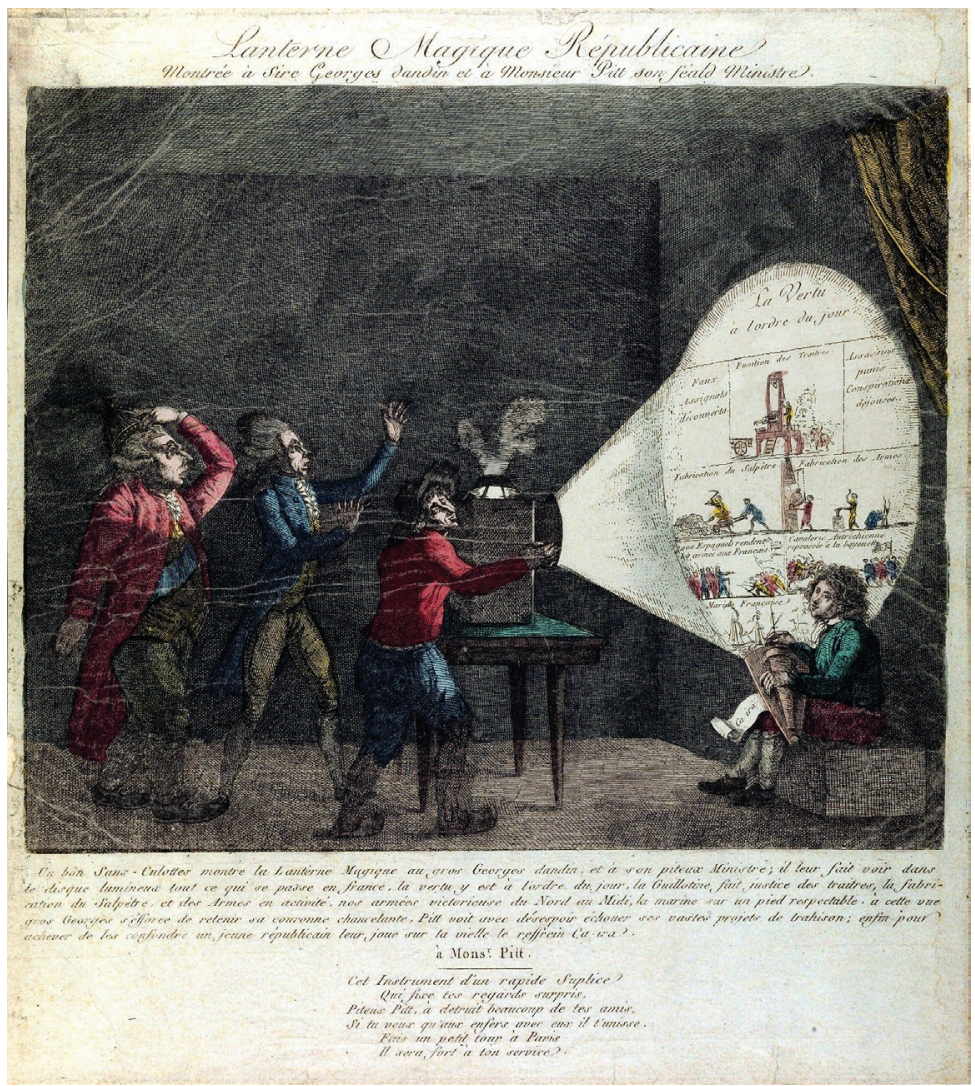

Figura 5

4 Una copia xilografiada del aguafuerte original aparece bajo el título Lanterne magique republicaine montrée à sir Georges Dandin et à monsieur Pitt son féald minister, après la bataille de Fleurus. 8 messidor an II (26 Juin 1794) en el número 283 del 1 de julio de 1794 de la Gazette Nationale ou Le Moniteur. En 1861 esta publicación es reunida para ser publicada como Universel Réimpression de L'ancien Moniteur. El número de la gaceta en la que aparece el grabado está incluido entre la página 100 y 101 del tomo 21.

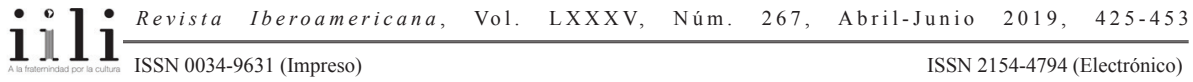


imágenes anti aristocráticas frente al Rey George III y a su primer ministro William Pitt. A los ojos de los británicos se hacen evidentes las persecuciones y decapitaciones a guillotina que le esperan a Inglaterra en caso que sus gobernantes osen entrometerse en la política francesa. Para quienes viven la Revolución, la linterna mágica es entendida como un instrumento científico capaz de realzar la visión de la manera en que lo hacen los espejuelos; mas es también un objeto tocado por lo sobrenatural. De acuerdo a Thomas L. Hankins y Robert J. Silverman, gracias al "amor al espectáculo" del público urbano del momento, la "magia natural y la física experimental se combinaron perfectamente" (citados en Trévien 43). Las características tecnológicas de la linterna mágica permiten construir una composición metafórica del tipo de conciencia política que buscan los revolucionarios (Weston 18). En el aguafuerte y en la litografía, el accionar del aparato hace visible un ente abstracto: el tipo de racionalidad que debe regir el escrutinio de la política; hace incluso dos cosas más: permite que se establezca un vínculo entre la máquina de proyección y la lámpara de Diógenes, a quien la luz le sirve para buscar la verdad en la naturaleza humana, y presenta como análogos, por un lado, el poder que tiene la linterna mágica para conmutar lo invisible en visible, y, por el otro, el rol desvelador de integridades de la sátira en la prensa ilustrada. Lo proyectado por la linterna mágica no consta propiamente de imágenes "reproducibles" sino que son más bien efectos repetibles, eventos únicos mostrados a más de un espectador; el que se trate de efectos explica por qué se conciben como apariciones y sus espectáculos, como "fantasmagorías". Críticos de la época sostienen que sus verdades, por más artísticas, diestras, inteligentes o ingeniosas, apuntan a lo que llaman la "inteligencia débil"; para ellos, estas formas visuales son tan poco confiables como lo son los sentidos y el conocimiento empírico (Weston 25).

Durante el Fin de Siglo, el uso de la metáfora de la linterna mágica como conciencia política parece servir como renovación republicana de votos patrióticos y como parte de la aparición ritual de iconografía neoclásica del republicanismo. No se trata ahora de eliminar las sombras de la realeza y el fanatismo religioso oscurantista sino de descubrir la verdad sobre la integridad de los políticos. Dentro de esta narrativa, los editores (e incluso los caricaturistas) de Caras y Caretas se conciben a sí mismos en el papel de los proyectistas itinerantes, los Savoyardos o Galantees, del período revolucionario. Son técnicos despojados de fanatismo, cuya labor consiste en capturar la atención mental e intelectual del público que acepta la persuasión del atractivo de su medio para poder, así, iluminar su honestidad interior.

En la imagen francesa y en la uruguaya, sus respectivos artistas han yuxtapuesto dos cualidades similares: las capacidades que tienen tanto la proyección mágica como la caricatura litográfica de hacer empíricamente presentes abstracciones e ideas mediante personificaciones, escenarios y narrativas. Entrado el Fin de Siglo, la linterna mágica, como tecnología visual, y su doble asociación a la ciencia y a lo sobrenatural, son

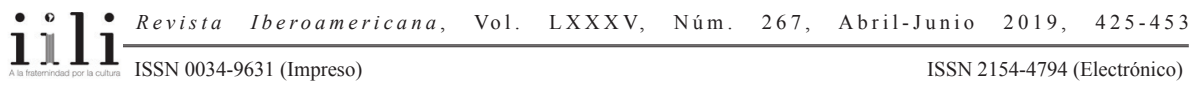


formas todavía relevantes de la cultura visual. En Hispanoamérica, su uso es común en las transformaciones y mutaciones llevadas a cabo por los espectáculos populares de comedia de magia y de física divertida (Maturana 84). Lo que en un uso de la linterna mágica representa la invocación fantasmal de lo invisible, en el otro representa el desvelamiento ilustracionista de la verdad; estos usos de la linterna mágica son trasladados al acto de observar la caricatura finisecular, que representaría el ejercicio de ingenio decodificador que requiere el desvelamiento de los niveles de integridad de los políticos identificados por la imagen. El presidente Idiarte Borda se muestra así como el Rey Momo de una carnavalesca República de Parva Domus Magna Quies ${ }^{5}$ haciéndose autobombo.

Al ser capaces de ridiculizar, e incluso difamar, las imágenes son también espacio para la transgresión del orden social. Se representan allí juntos y revueltos individuos culturalmente diferentes y situaciones carnavalescas que parecen favorecer a las clases medias emergentes en desmedro de la vieja aristocracia, y el público de sectores socialmente más bajos es partícipe de burlas a personajes de la élite política. Las caricaturas, además, deshumanizan a estos individuos convirtiéndolos en series de "descriptores", atributos ideológicos, fuerzas políticas, posiciones e intereses que reconocer rápidamente.

Los ataques no solo cuestionan el prestigio de los atacados sino que, además, por oposición, colocan la posición prestigiosa del atacante y sus armas en una instancia moral suprema. La agresividad de los métodos usados por la prensa para cuestionar la integridad personal se responde con métodos aún más agresivos para defenderla. Caricaturas satíricas pueden dar lugar a retos a duelo so pretexto de reparar el honor del ofendido. "[P]ara la segunda mitad del siglo diecinueve", afirma David S. Parker, "los políticos y periodistas uruguayos habían desarrollado su propia noción de responsabilidad, a la que se referían frecuentemente como 'responsabilidad de caballero'. Ser responsable significaba estar dispuesto y listo a respaldar palabras y acciones de la manera en que lo dictaban los códigos de honor y, si era necesario, en el terreno del duelo" (116). Contemporáneamente, en otro extremo del continente, el Código nacional mexicano del duelo por el Coronel de Caballería Antonio Tovar, publicado en 1891, describe incluso el tipo de caricaturas que constituyen ofensas que merecen la satisfacción de un duelo (Piccato 339). Los duelos como mecanismos para reparar el honor no se limitan al Uruguay, el México o el resto de la Hispanoamérica

5 El 8 de diciembre de 1894 el presidente Idiarte Borda participa en una opulenta Gran Tenida Magna Extraordinaria celebrada por la República de Parva Domus Magna Quies montevideana en honor del Club Turista de Buenos Aires y de la Parva Domus Bonaerense. Asistieron más de doscientas personas. Los miembros de esta república ficticia, todos de la alta sociedad, celebraban el carnaval todos los años y rendían homenaje al Rey Momo y al Marqués de Calatrava. Así, por lo menos, es como figura en la crónica de la celebración del 2 de marzo de 1897.

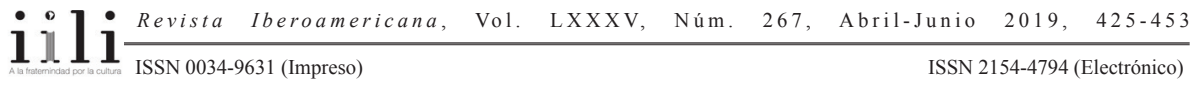


de esos años, sino que son moneda corriente entre figuras públicas y periodistas en Francia, Alemania y otros países europeos. Fiscalizadores y fiscalizados aceptan esta manera de de resolver el escrutinio de la integridad. "Los escritores y periodistas que le explicaban a los lectores mexicanos los beneficios de batirse en duelo enfatizaban el papel de la opinión pública en la solución de asuntos de honor", escribe Pablo Piccato (331), para agregar más tarde:

En el contexto de los desafíos a duelo, el tener derecho a participar en ellos estaba reservado a la educada población urbana de clase alta de donde venían la mayoría de los duelistas. Así, el código de honor establecía paridades excluyendo de esta práctica mayoritariamente al resto de esta gente-garantizando al mismo tiempo que se preservaran las reputaciones públicas y privadas. (344)

La idea de una representación efectiva de la soberanía popular mediante la fiscalización ejercida por la opinión pública a la clase política se traiciona cuando los vínculos entre la tecnología del honor y posición de clase se hacen claros. Los duelos sirven para distinguir y unificar una élite moderna en formación; los periodistas y los políticos, como formadores de opinión pública, son parte de una misma élite. También podría decirse que el espacio de enfrentamiento agresivo que toma forma en una revista como Caras y Caretas es parte activa de este proceso de distinción y unificación de sectores privilegiados. A pesar de su actitud antagonista, esta publicación tiene los mismos intereses clasistas que los grupos insultados (casi, sin excepción, masculinos). El precio de ser admitido en el espacio de la formación de la opinión pública es el de asumir "responsabilidad" por las acciones, lo que es aceptado por la prensa.

Así como el duelo es visto como una práctica modernizadora que coloca a sus participantes en un medio cosmopolita y progresivo al hacerlos partícipes de un código civilizado regulador de estatus y respetabilidad capaz de reparar distinciones de jerarquía social hechas difusas por la democratización liberal; la producción de caricaturas es vista de manera semejante puesto que los artistas forman parte entonces de una comunidad internacional de hombres que conceden y reclaman integridad en sus gobernantes fiscalizando el ejercicio del poder mientras mantienen su separación para con los sectores populares.

El declive, mas no desaparición, en Hispanoamérica de la "representación política de la semejanza", y del "desvelamiento fantasmagórico ilustracionista" a fines del siglo XIX puede explicarse de muchas maneras que puede argüirse están interrelacionadas dentro de la esfera de la formación moderna de la opinión pública. En México y en el Uruguay, por ejemplo, se vincula a la crisis democrática que envuelve procesos de industrialización, urbanización e inmigración. Al estallar la Revolución mexicana de 1910 y, en Uruguay, la de 1897, se produce un gran control gubernamental de los medios de prensa. En el caso uruguayo, el gobierno de Idiarte Borda puso en efecto el 3 de

\begin{tabular}{l}
1110 \\
\hline ISSN 0034-9631 (Impreso)
\end{tabular} 
febrero una censura que terminó con más de una publicación satírica (Cerda 19); ${ }^{6}$ el último número de Caras y Caretas sale en Montevideo el 28 de ese mes, poco después de haber atacado verbal y visualmente al presidente y a uno de sus militares favoritos. Con el declive de la caricatura satírico política también declina la tecnología del honor.

Para mediados de la década de 1880, muchas ilustraciones son hechas usando fotografías como base para xilografías o dibujos litográficos. Los retratos hechos para los diarios, por ejemplo, eran trazados rápida y mínimamente y su producción suponía con frecuencia el uso de clichés. Retratos xilográficos con base fotográfica producidos para revistas ilustradas, como aquellos publicados por revistas ilustradas fundadoras como las británicas The Illustrated London News y The Graphic o la francesa L'Illustration, requieren mayor tiempo para su ejecución y una tecnología fotomecánica más costosa. La misma regla se aplica a los otros tipos de ilustraciones comunes, tales como las vistas naturales o arquitectónicas. Dentro de este proceso de cambio que se mueve entre el aguafuerte, la xilografía, la litografía y la fotografía, como revela Russell Marble en su ensayo, un lenguaje de imágenes gráficas compite con el verbal, que depende para sus efectos de imaginería sensorial más vasta. Enfocándose en la diversa percepción del mundo permitida por cada uno de los cinco sentidos, ilustraciones aparecidas en 1890 y 1901 en la revista Caras y Caretas, en Uruguay y Argentina, respectivamente [Fig. 6], parecen corroborar que aquella pugna por el dominio de la representación
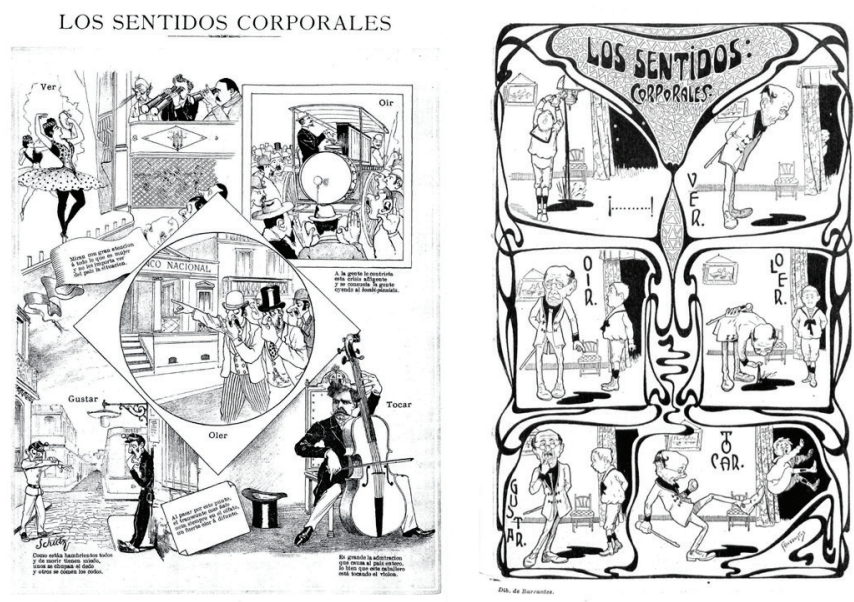

Figura 6. Cortesía: Biblioteca Nacional de España

6 "La Carcajada no duró más de dos meses; dejó de publicarse a raíz del decreto de censura de 3 de marzo de 1897, que prohibía a los diarios y otros impresos dar noticias políticas del país, informar sobre movimientos de las tropas y expresarse en forma descomedida sobre la persona y sobre la actuación de los miembros de los poderes públicos" (19).

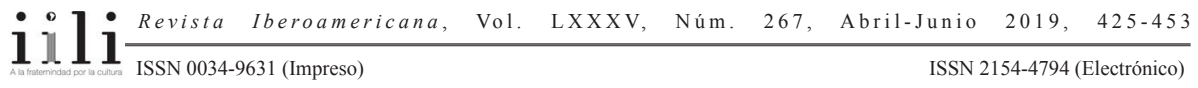


sensorial identificada por Marble en los Estados Unidos es también un hecho en la Hispanoamérica finisecular.

Antes que los fotógrafos y los reporteros in situ tomen el control, dejando detrás de ellos el rol protagonista que juegan los ilustradores gráficos y los escritores de folletin, los escritores periodísticos más populares del Fin de Siècle hispanoamericano son los cronistas literarios. Compitiendo con los primeros reporteros, y tratando de conseguir lo que también intentaban los periodistas gráficos, los cronistas buscaban colocar a sus lectores en medio de la acción, rodearlos (mediante el uso abundante, por ejemplo, de sinestesias) de la percepción virtual de ser partícipes de una experiencia huidiza; haciendo posible para ellos "comprehender" efectivamente la modernidad o, en palabras de Charles Baudelaire, entrar "en la muchedumbre" (87). Cronistas hispanoamericanos como José Martí se apropian de la lógica que articula las imágenes que acompañan los reportajes escritos que produce la prensa gráfica estadounidense. De manera complementaria a este trabajo verbal, ilustradores como José Guadalupe Posada son en la práctica cronistas visuales que consiguen "estremecer" a sus lectores al darles un punto de vista interior desde el cual evaluar una situación [Fig. 7].

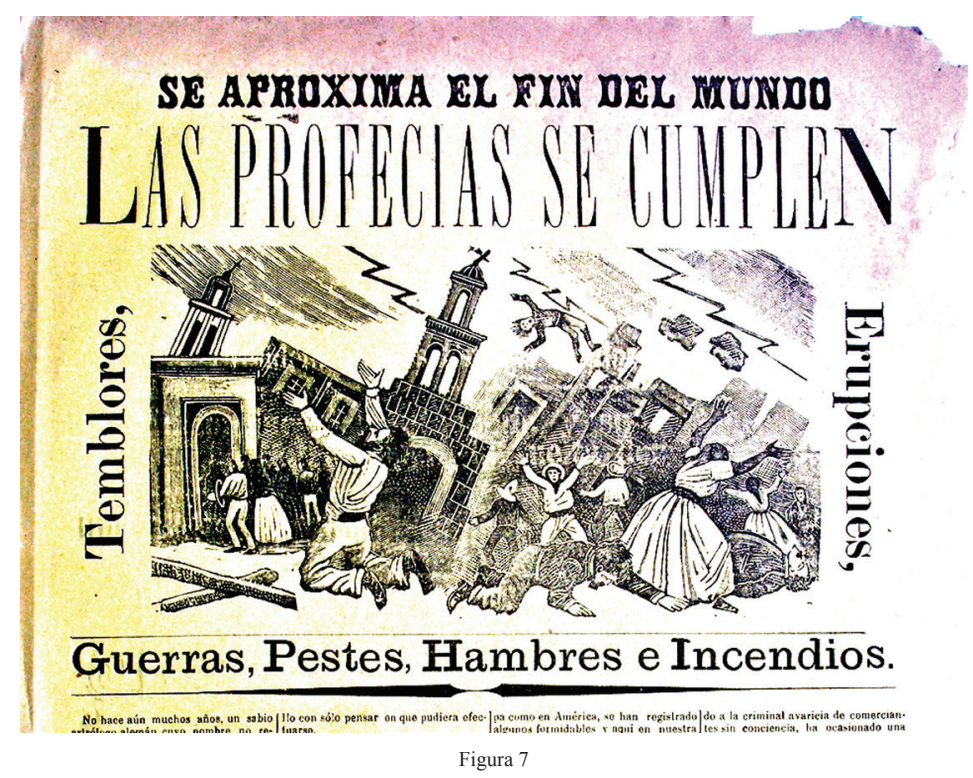

Los agudos recursos críticos finiseculares desplegados por la caricatura, acompañados de las estructuras conceptuales traídas por la diagramación contemporánea en las publicaciones ilustradas, dieron forma a otras maneras modernas de leer información visual presentada de manera segmentada y simultánea. Las revistas británicas The Graphic

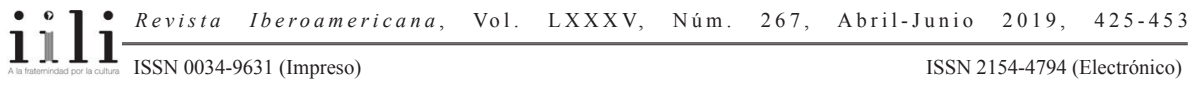


y Punch contienen innumerables ejemplos que muestran la yuxtaposición de unidades traslapadas y desplegadas en cascadas irregulares cuyo vínculo es la enumeración secuencial o la catalogación. Estructuras similares aparecen contemporáneamente en The Daily Graphic y el periódico World de New York. Caras y Caretas hace uso continuo de estos tipos de órdenes fluidos poniendo particular énfasis en la contigüidad de simetrías, paralelismos, oposiciones especulares (antonimias y secuencias de "antes y después", entre otras) [Fig. 8] y contenido semántico. Aislados o en grupo, estos

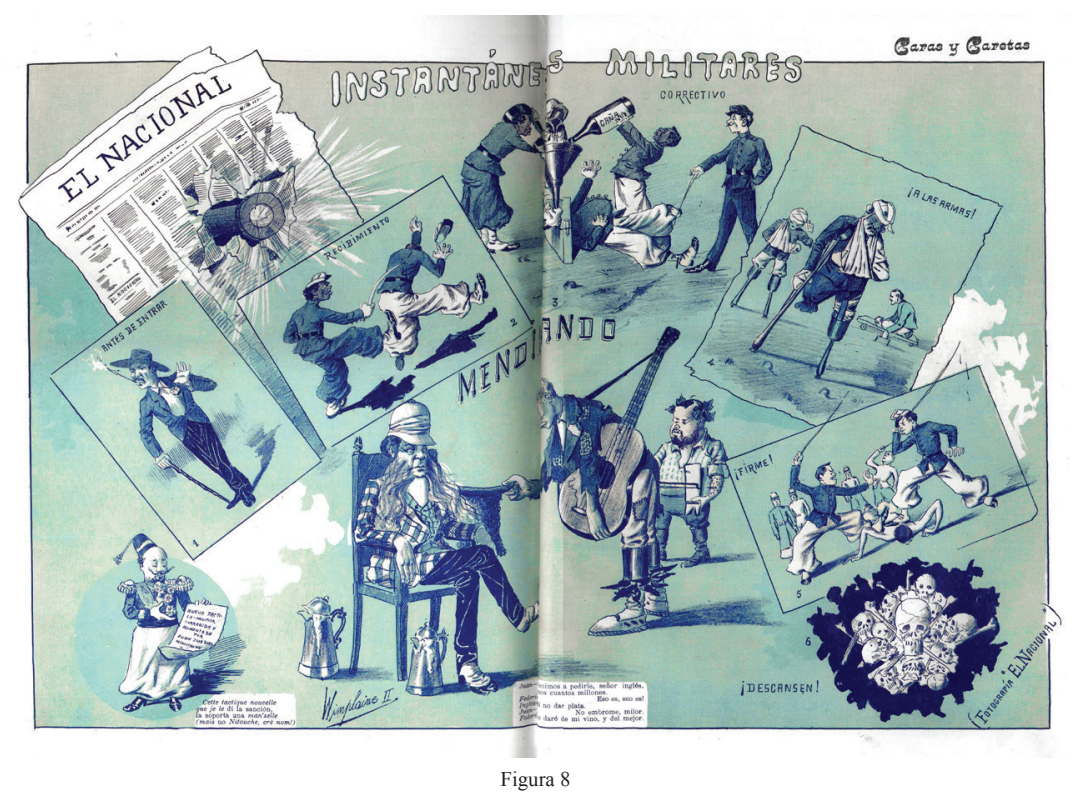

tipos de recursos visuales promueven una lectura, una manera de ver, no unidireccional rectilínea, no escritural, así como también la preservación del vistazo para la aprehensión de narrativas complejas o abstractas. Entre las unidades usadas, la revista canibaliza formatos fotográficos dentro de la esfera del dibujo. Cartes de visite litografiadas, por ejemplo, satirizan la dudosa capacidad que tiene la fotografía para representar la verdad indiscutible, mostrando para ello una secuencia de diecisiete combinaciones de escenarios y poses para un retrato oficial del presidente [Fig. 9].

La época uruguaya de Caras y Caretas se cierra en 1897 dominada completamente por el dibujo litográfico. Su periodo de inversión fuerte en la impresión fotomecánica con semitonos se inicia en 1898 al ser relanzada en la otra ribera del Río de la Plata. Una vez en Buenos Aires, la naturaleza de la publicación cambia a partir de su modelo comercial

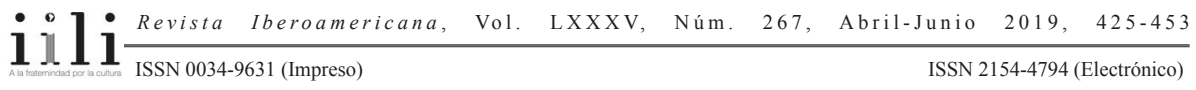




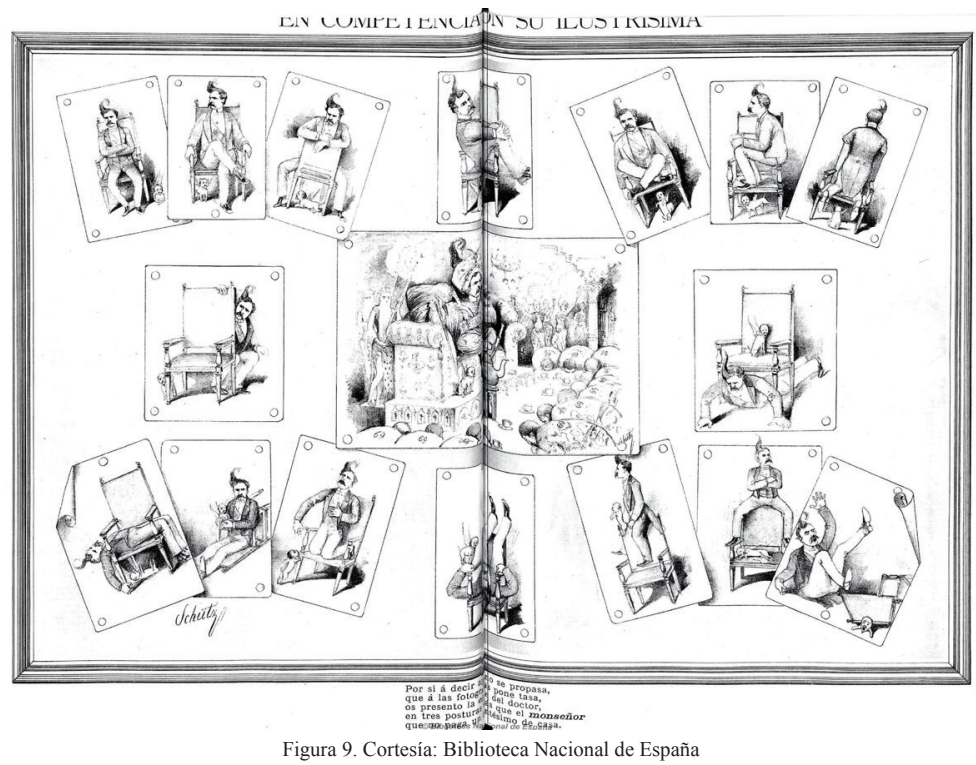

y con este se da un giro en su horizonte para apartarse de Europa y dirigirse hacia los Estados Unidos. "La nueva orientación tendía, en cambio," escribe Geraldine Rogers, "a seguir el modelo norteamericano, con empresas independientes a la esfera política. Un factor determinante del cambio era la emergencia de un nuevo público que el informe [se trata del Anuario de la prensa argentina 1896] identificaba como "el pueblo"" (66). Se trata ahora del modelo de la Revista Popular Ilustrada. El distanciamiento que tiene la renovada Caras y Caretas para con la actualidad política determina que su fundador, el español Eustaquio Pellicer, deje la dirección al argentino José S. Álvarez para evitar un impacto negativo en el mercado luego de la Guerra de Cuba de 1898 (29-30). La revista está ahora dirigida con mayor énfasis a las clases medias y a lectores de ambos sexos, incluye publicidad que llega a ocupar casi el $40 \%$ del material impreso, y cuenta para su difusión con las redes ferrocarrileras. Subtitulada Semanario festivo, literario, artístico $y$ de actualidades, durante su segundo periodo Caras y Caretas despliega caricaturas políticas en sus portadas siguiendo el estilo de su contemporánea estadounidense Puck; pero, a pesar de esta presencia prominente que se le da al dibujo, el fotograbado es su medio dominante. La diagramación de la revista muestra una negociación continua entre las previas representaciones visuales de estructuras conceptuales y las particulares propiedades visuales traídas por las reproducciones fieles que resultan de las fotografías y las instantáneas convencionales de la época. La composición de la página que abre el primer número argentino, por ejemplo, parece tomar como modelo la diagramación del artículo "An Amateur Photographer at the Zoo", publicada en la londinense The Graphic

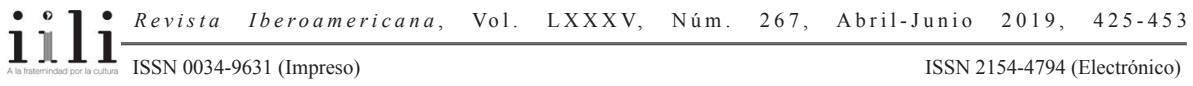


en $1885,{ }^{7}$ la primera página en exhibir reproducciones fotográficas en semitono dentro de una revista popular ilustrada. La diversidad de los temas que se cubren, requieren, sin embargo, un tratamiento distinto. Algunos formatos necesitan únicamente que se remplacen los dibujos. En ciertos casos, cuando los editores tratan de adaptar retratos fotográficos y vistas a la diagramación dinámica y fluida usada previamente con el dibujo litográfico, los resultados son problemáticos: las fotografías traen consigo información visual no deseada -ruido comunicativo- y es, por lo común, difícil reconocer los objetos fotografiados debido a la escala en la que se presenta la toma. Las fotografías que siguen convenciones pictóricas se acomodan mejor a la diagramación simétrica de las estructuras previas. La revista, por otro lado, no abandona la inclusión de dibujos fluidos y de imágenes presentadas de manera simultánea. Provocar los tipos de lecturas que permiten los dibujos es, sin embargo, difícil cuando se trata de usar las instantáneas tomadas por los reporteros. La diagramación de las revistas necesita frecuentemente del apoyo de secuencias numéricas y de largas explicaciones textuales. Otros intentos de adaptar fotos a lecturas multidireccionales no son tampoco muy exitosas puesto que incrementan la distracción que ya traen consigo las tomas. Las instantáneas de los reporteros son por lo común comunicativamente muy ruidosas, y este problema es realzado por el uso de estructuras yuxtapuestas convencionales. Algo semejante ocurre con los intentos problemáticos de usar la fotografía como una herramienta crítica en combinación con la caricatura. Los retratos fotográficos en semitono que se recortan para remplazar los rostros de base fotomecánica de caricaturas litografiadas no son solo ruidosos sino también mínimamente significativos; además de esto, los intentos que se llevan a cabo para producir caricaturas fotográficas dan por resultado efectos distorsionadores muy básicos. Podría decirse que el formato más efectivo para la instantánea del reportero dentro de las estructuras conceptuales usadas para la crítica sociopolítica es una serie de vistas informales que son producto de un paseo errante por la ciudad, al estilo del flâneur, en busca de señales de deterioro y negligencia civil.

El alcance crítico de la representación fotomecánica durante la etapa argentina de Caras y Caretas es en realidad muy limitado; está a favor y sirve más bien para reforzar el discurso del progreso ofreciendo evidencia empírica de las ideas de decadencia y degeneración, del aparentemente infinito avance de la ciencia, y del mejoramiento del estilo de vida traído por la nueva tecnología. El telón de fondo de estos muestrarios es el darwinismo y las teorías de evolución social, argüidas a través de imágenes de exploraciones antropológicas y de exhibiciones que contrastaban la civilización y la barbarie. Imágenes de individuos físicamente "degenerados" hacen posible que el lector

7 La nota "An Amateur Photographer at the Zoo", que incluye lo que los editores definen como "Facsímiles de las fotografías", aparece en Londres, en el número de The Graphic que corresponde al 5 de septiembre de 1885 .

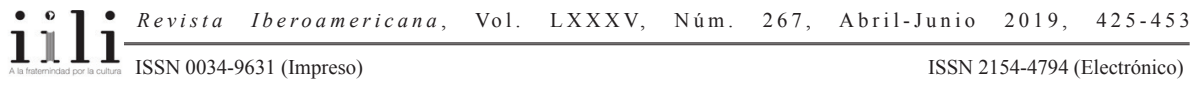


o lectora se coloque a una distancia sin riesgo del fenómeno de la regresión biológica. Disciplinas como la fisionomía son respaldadas por crudas comparaciones de rasgos faciales catalogados; como se hace también con la frenología mediante la citación de medidas craneanas de figuras históricas que son apenas distinguibles a partir de sus posados retratos fotográficos; artículos acerca de hospitales psiquiátricos subrayan la obvia diferencia que existe entre la normalidad y la demencia contrastando fotograbados de fotografías posadas de su personal y fotos de prontuario de sus pacientes. Los criterios composicionales usados para imágenes como éstas y para la exhibición de anormalidades anatómicas son visualmente vinculados a la regresión genética y a la criminalidad antropométrica. Teniendo este telón de fondo, la ciencia y la tecnología se convierten en el centro de atención. El conocimiento científico ofrece un sentimiento permanente de progreso sin fin; y la tecnología visual, en particular, ofrece una profundidad que va más allá del detalle fotográfico normalmente desestimado por el ojo. A partir de este punto, lo invisible es convertido en verdad visual irrefutable puesta al acceso del público masivo a través de la representación fotomecánica como forma de ver, como subcultura de un nuevo régimen escópico.

La distancia deja de ser un problema en la verificación de fenómenos celestiales. Los lectores son capaces de ver planetas lejanos e inclusive la propia tierra desde lo alto; se ofrece al alcance de la mano una vista fiel a vuelo de pájaro así como también la experiencia sensorial de otras especies: moscas y peces, por ejemplo. La dimensión o tamaño tampoco son un obstáculo, al lado de la experiencia del astrónomo también se presenta la del microbiólogo como si fuera un acto de visión. Las imágenes fotográficas de placas expuestas a los Rayos X y a la luz negra (fotografía ultravioleta de onda larga) dan forma a la percepción visual que atraviesa la materia sólida. Fotografías de ectoplasmas y de huellas dejadas sobre papel sensible por los llamados "rayos N" se convierten en evidencia física de la existencia de entidades inmateriales tales como el alma humana y el pensamiento. La fotografía también hace posible capturar acciones que son demasiado rápidas para ser percibidas a simple vista: el destello de un relámpago, por ejemplo, o la caída y salpicadura de una gota de agua. Algunas imágenes fotográficas reproducidas en rápida secuencia tomadas por una cámara de alta velocidad dan la impresión de ser un film cinematográfico. Este tipo de imágenes que representan movimiento preceden a la invención del cinema; su presentación en secuencia no trae a la mente de manera inequívoca el movimiento cinemático puesto que el público está familiarizado con tecnologías como el gabinete óptico o el praxinoscopio. Imágenes impresas de secuencias de películas de cine son indistinguibles de una serie de fotografías de alta velocidad, como se puede ver en el primer aviso publicitario para kinetoscopios publicado por Caras y Caretas en 1900. La emergencia del cinema como forma popular de entretenimiento masivo parece haberse estabilizado y estandarizado dentro de los medios impresos alrededor de 1907 y, por lo menos en Caras y Caretas, en una

\begin{tabular}{l}
1110 \\
\hline ISSN 0034-9631 (Impreso)
\end{tabular} 
representación específica de movimiento marcado por la visualización de la perforación de arrastre de los bordes de la película cinemática. El hecho de que el número 508 de la revista, aparecido el 27 de junio de 1908, contenga en su sección "Menudencias" dibujos que representan el cinema y que hagan un comentario que mezcla cinematografía y política al fundir la tira cómica con el rollo de film [Fig. 10], nos regresa a uno de los

MENUDENCIAS

CINTAS CINEMATOGRÁFICAS
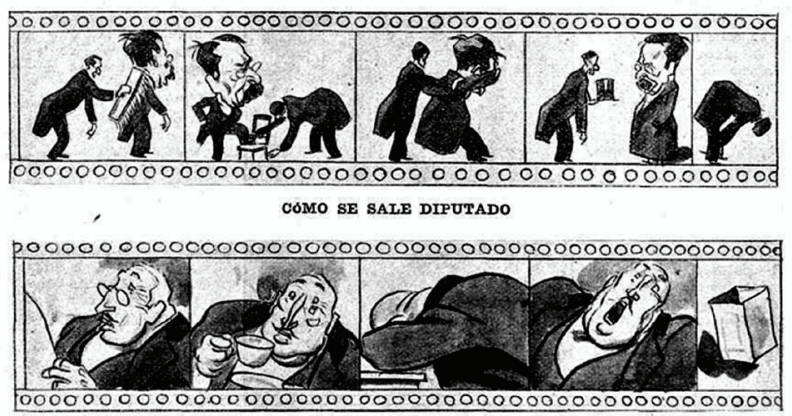

COMO SE FREPARA UN DISCURSO ELOCUENTE
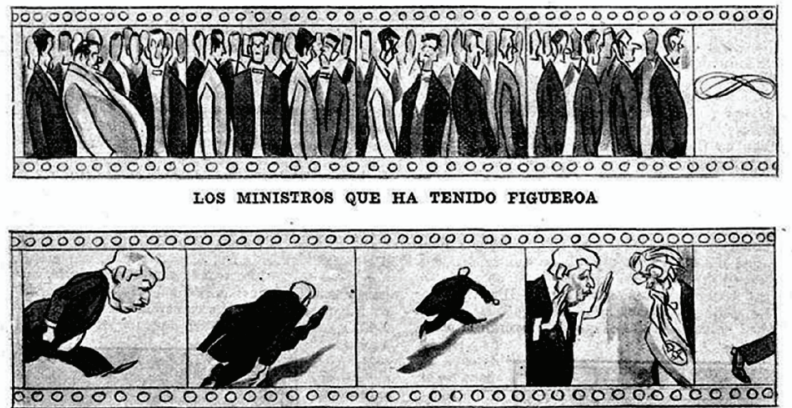

COMO SE PIERDE UNA BANDA

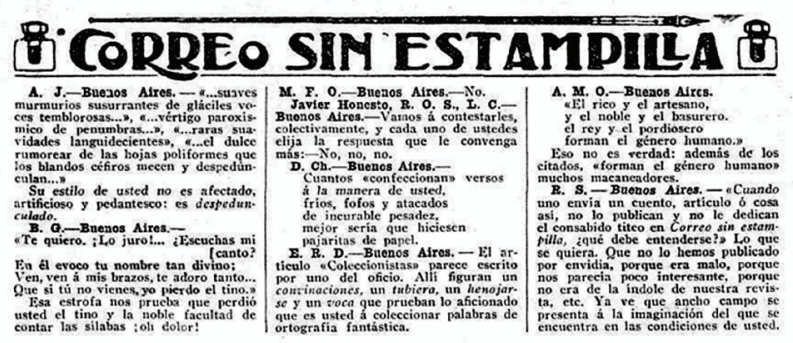

Figura 10. Cortesía: Biblioteca Nacional de España

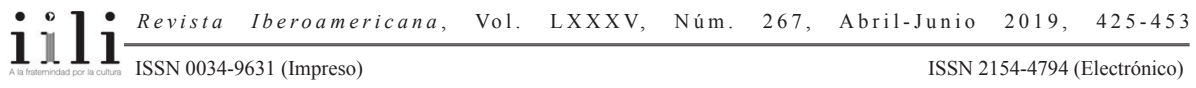


temas tocados al inicio de este ensayo: la competencia entre dibujos y fotografías por la hegemonía sobre la representación visual, ilustrada con precisión por el grabado de la carátula de Caras y Caretas del 4 de enero de 1902 [Fig. 11].
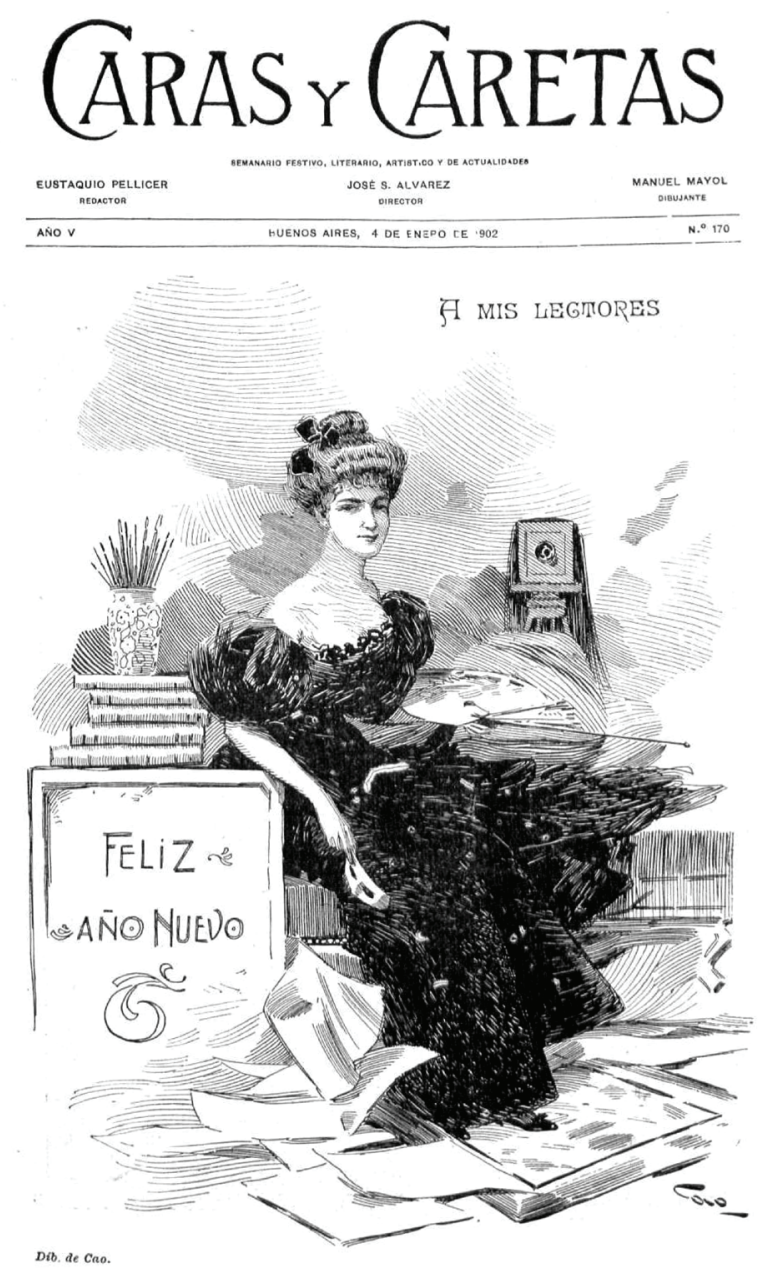

Figura 11. Cortesía: Biblioteca Nacional de España

Me gustaría sostener que el uso que la revista argentina hace de la representación fotomecánica consigue con éxito darle al público de clase media, de una de las capitales más europeas de la Latinoamérica del Fin de Siglo, alientos reiterados sobre la seguridad

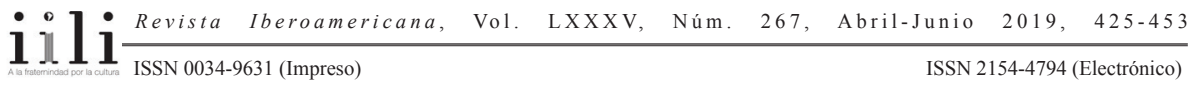


de su futuro: la modernización es un proceso indetenible de alcance en apariencia infinito. Y también me gustaría argüir que el uso que hace del dibujo, por otro lado, es más crítico, aunque ambivalente, puesto que sirve además para diseñar la propaganda de la nueva tecnología y de las mercancías industriales importadas que se le relacionan. Como ocurre en la imagen "El origen del hombre según el Dr. Ameghino" (de abril de 1907), que se vale del darwinismo [Fig. 12], un dibujo de estructuras fluidas y multidireccionales le

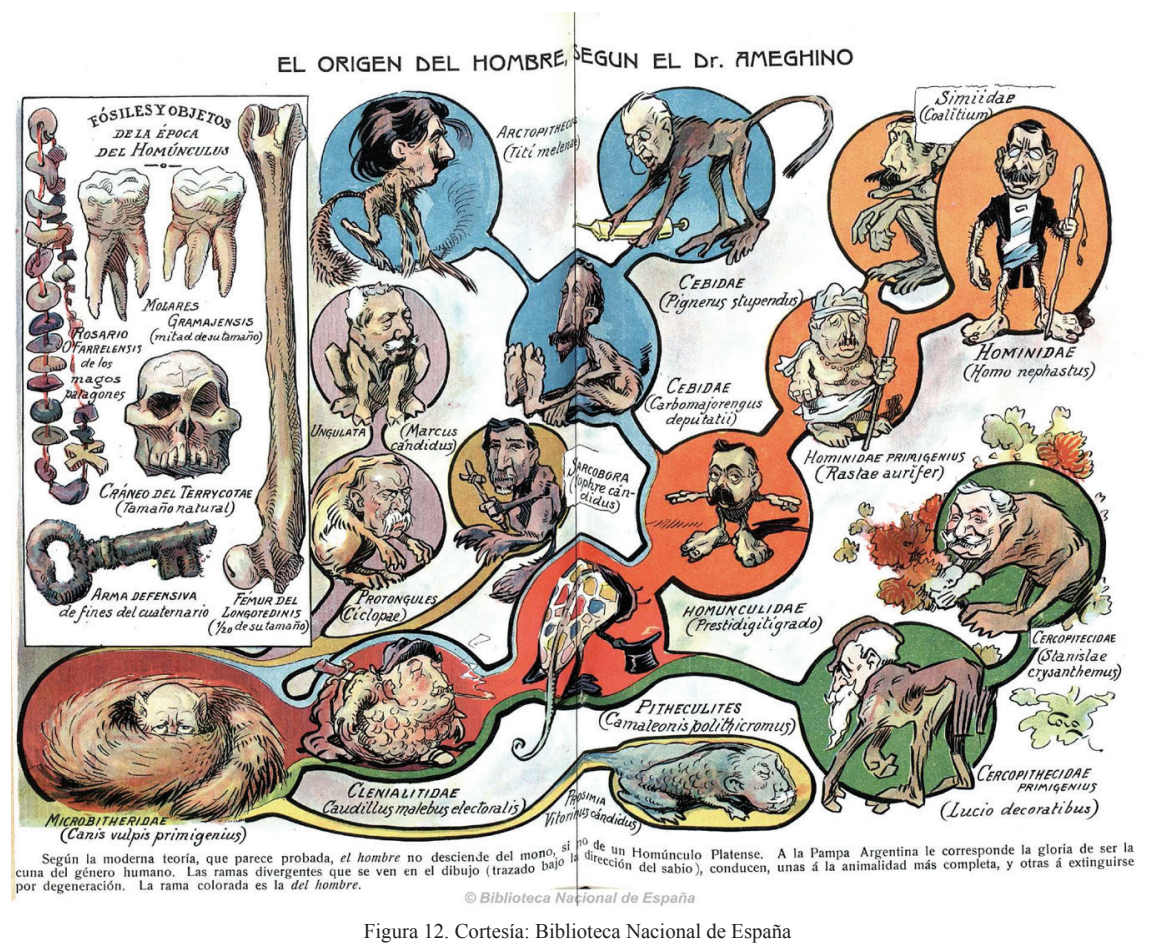

sirven para criticar mordazmente la mayoría de las áreas representadas positivamente por los fotograbados incluidos en la revista. El dibujo se usa también para cuestionar el estado cerebral y los rasgos faciales del presidente burlándose de la frenología y la fisionomía; y para satirizar el interés del momento tanto en el crimen como en la antropometría criminal presentando la primera como una moda deportiva [Fig. 13], e imitando la segunda por medio de una caricatura del presidente en la cual se exhiben rasgos de otros políticos conocidos por su comportamiento "extremo". A distancia de la representación de la linterna mágica, pero aún así relacionada al "desvelamiento fantasmagórico ilustracionista" como manera de ver, una caricatura que se vale de

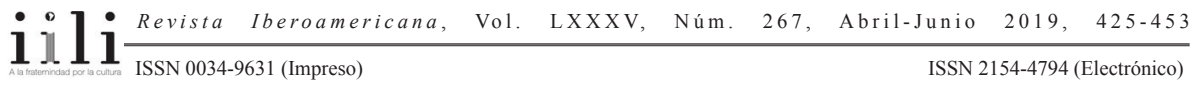




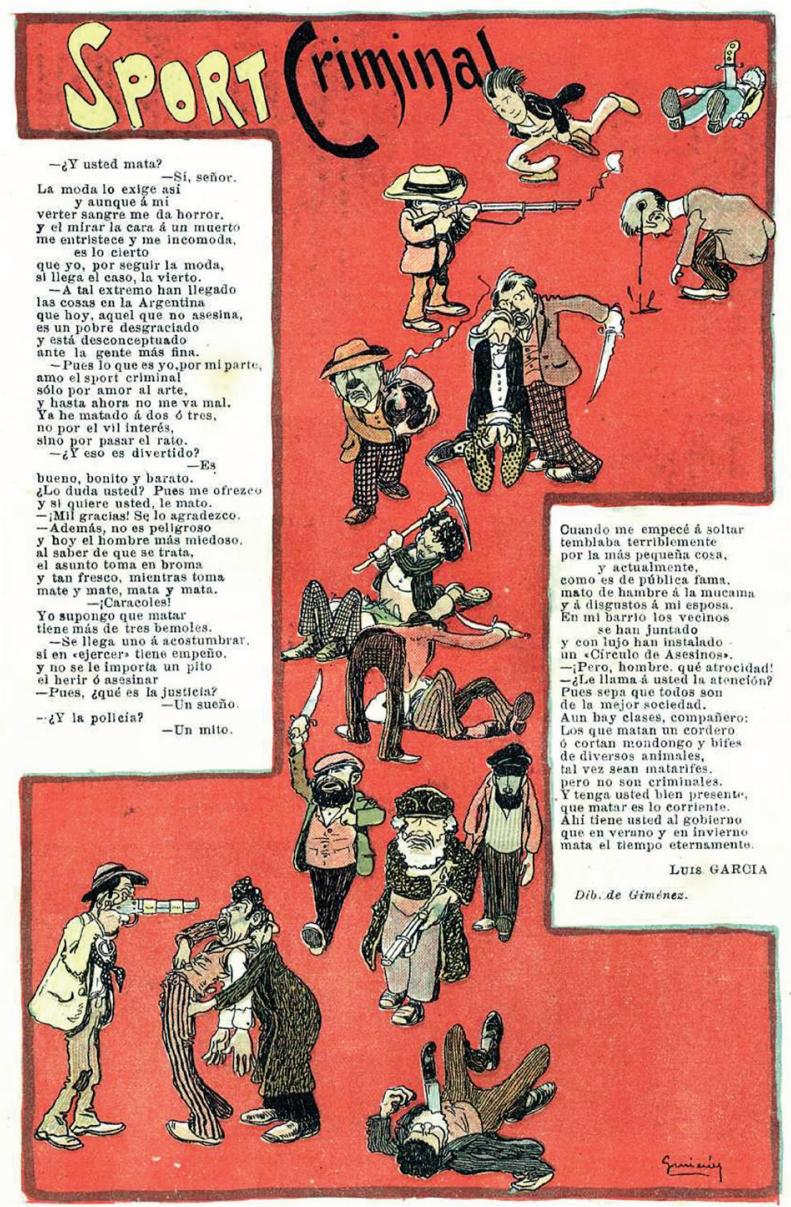

(c) Biblioteca Nacional de España

Figura 13. Cortesía: Biblioteca Nacional de España

la tecnología de los Rayos X muestra lo sumamente efectiva que es en el revelado de las debilidades o fortalezas del carácter de los políticos [Fig. 14]. Los microscopios hacen visible la cruda lucha por el poder, escondida a los ojos del público, en la que se involucran los políticos. Como herramienta crítica, el dibujo es incluso usado para cuestionar la propia visión y los fundamentos del dominio de lo visual en el Fin de Siglo sirviéndose del principio de la "ilusión óptica" [Fig. 15].

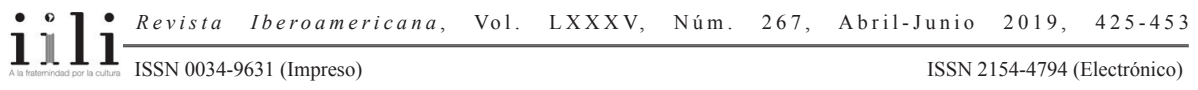




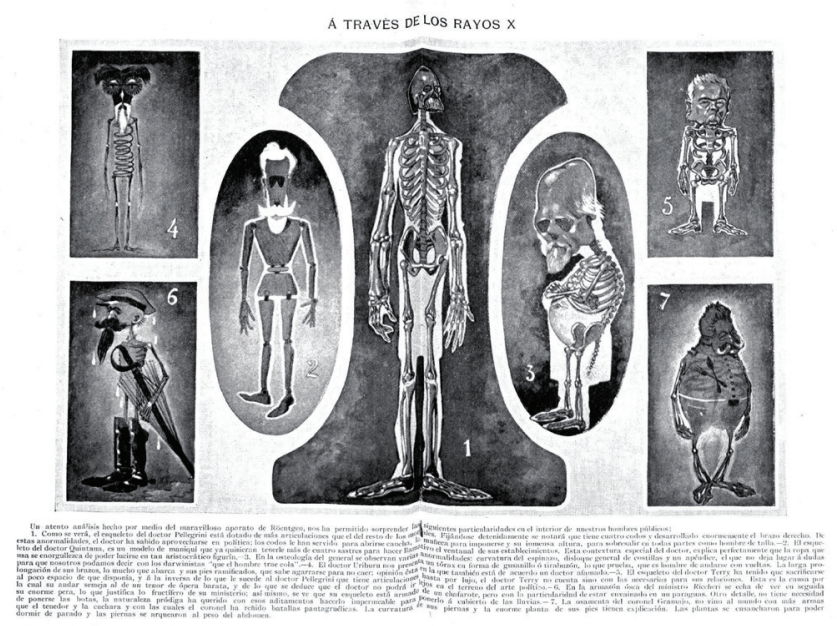

Figura 14. Cortesía: Biblioteca Nacional de España

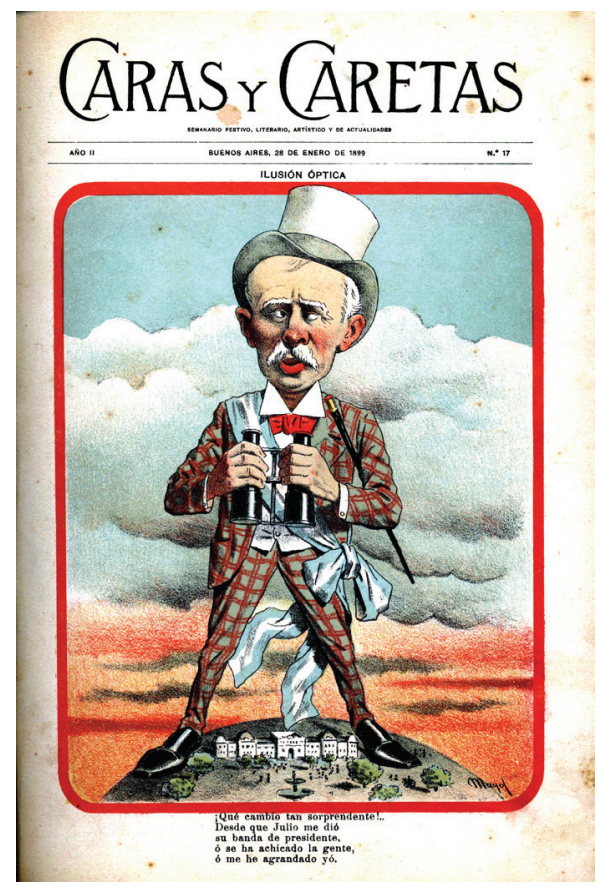

Figura 15. Cortesía: Biblioteca Nacional de España

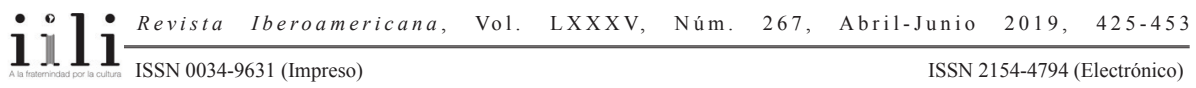


Si el final del siglo XIX provoca páginas de sátira gráfica acerca del futuro, enfocada en su mayoría en la superabundancia de aparatos que parece traer el siglo $\mathrm{XX}$; por otro lado, también apoya la idea de un progreso moderno dándole forma a un discurso visual que hace uso de representaciones fotomecánicas de disciplinas empíricas, nuevas tecnologías y temas sensacionalistas de los reporteros, entre otros aspectos, con el fin de tratar los valores que yacen en el núcleo de las teorías de evolución social. De esta manera los dirigibles venden mejor salud; los accidentes de tránsito confirman la supervivencia del más apto; los rayos $\mathrm{X}$, acceso empírico a verdades comerciales invisibles [Fig. 16]; la fisionomía y la frenología, indulgencia decadente de moda; y, paradójicamente, las ilusiones ópticas (en visión translúcida o en escorzo), alertas acerca de la evaluación incorrecta de la verdad que es producto de confiar demasiado en la representación visual.

Para 1908, con la publicación de representaciones fotomecánicas científicas relacionadas al sonido, la visualidad parece haber ganado la batalla por la predominancia sensorial en Caras y Caretas; y la fotografía, la competición contra el dibujo por la hegemonía sobre la representación visual. Imágenes fotomecánicas como las mencionadas son pronto seguidas por ilustraciones científicas lineales [Fig. 17]. Me gustaría sostener que, a pesar de las ventajas tecnológicas y económicas de la fotografía, las estructuras multidireccionales de percepción relacionadas al dibujo no acaban siendo totales "víctimas del progreso" ni devienen obsoletas. Como

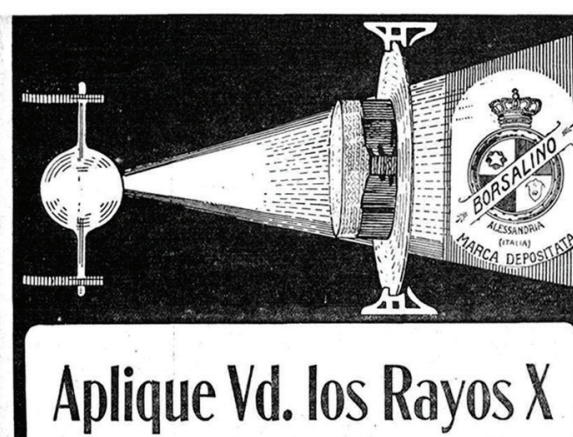

para distinguir la calidad de un sombrero y usted notarí que únicamente los que lleven la marea "Borsalino" son los que le convienen, tanto por la calidad como por la forma, siendo á la vez los más elegantes y los de más duración.

Canotier, marca Borsalino, en paja de Italia, í. ...... \$ 6. -

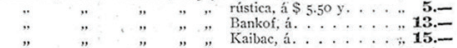
Sombreros, marca Borsalino, galeritas, formas de moda, $\$$ I2 y $\$ 10$. Sombreros de paja Panamá tenemos en venta un surtido recién recibido Gran variación de calidades de $\$ 200$ á $\$ 18$

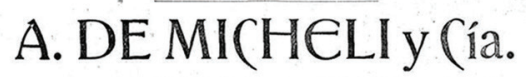

Av. de MAYO, 1001 - RIVADAVIA, 1002 SUCURSALE:

C. Pellegrini, 340 - (uyo, 1102 - B. Irigoyen, 502 BUENOS AIRES

Pidan catálogo se remite gratis

Figura 16. Cortesía: Biblioteca Nacional de España tecnología de una manera de ver, no desaparecen sino que se repliegan detrás de su habilidad para provocar una experiencia sensorial virtual con efectividad. Para la fotografía es difícil, aunque no imposible, conquistar todas las áreas. A pesar de tener como objetivo el colocar al espectador en medio de la acción, las instantáneas de los reporteros son incapaces de llegar allí: trípodes, gente y objetos se cruzan en su camino. Sus fotos muestran espaldas de individuos o

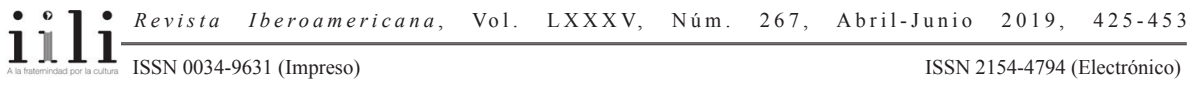




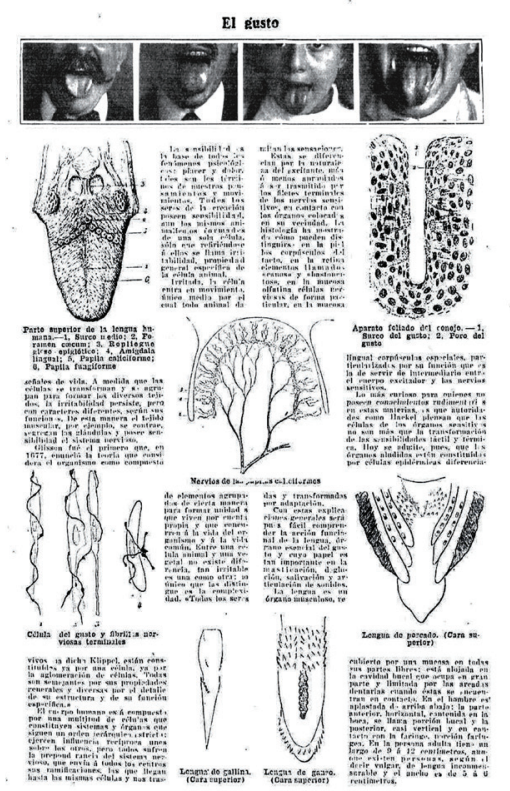

๑ Biblioteca Nacional de España
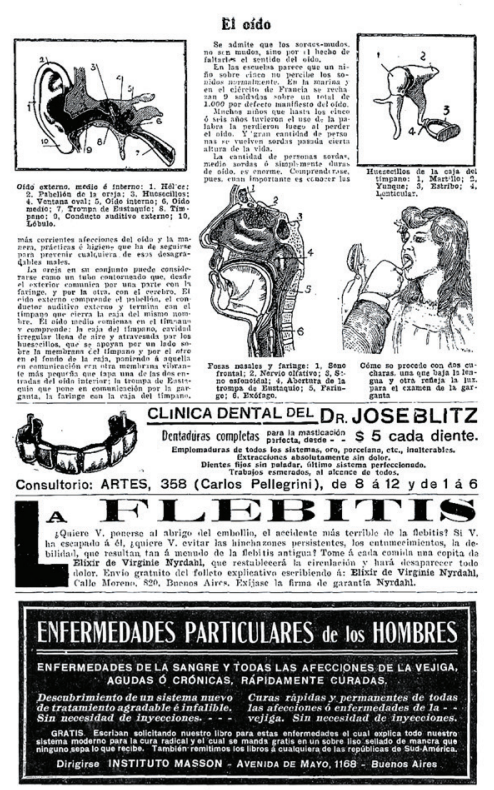

๑ Biblioteca Nacional de España

Figura 17. Cortesía: Biblioteca Nacional de España

su conciencia de la presencia de la cámara. La invención de la cámara de cajón les permite acercarse a las acciones, pero eso no es suficiente para crear en los lectores la percepción visual de habitar el baudelaireriano vórtice que los cronistas literarios del Fin de Siglo han conseguido con tanta eficiencia. Estos últimos, como he ya señalado, no buscan meramente informar sino causar escalofríos en sus lectores. Experiencias como un intento de asesinato político son en la práctica inalcanzables para cualquier reportero -aunque lo son para una cámara de circuito cerrado de televisión-, estos llegan demasiado tarde o la tecnología disponible no es lo suficientemente rápida como para capturarla. El cronista gráfico del grabado no espera ser un testigo, como le era necesario al fotógrafo; en lugar de esto, busca establecer empatía sensorial con el fin de conseguir que sus lectores "aprehendan" visualmente la experiencia. No se trata de exhibir los eventos conforme ocurren ni cómo realmente son, sino de ofrecer al público un lugar en el cual posicionarse, desde donde poder percibir, ofrecer una explicación y entender aquello que está ocurriendo a su alrededor. Tal logro haría posible que los cronistas literarios coloquen a sus lectores en una posición privilegiada que es inalcanzable a la experiencia de ningún testigo. Los objetivos de estos cronistas son reflejados por las ilustraciones de la prensa gráfica contemporánea, que también busca alcanzar la meta de hacer accesible un tipo de "verdad más profunda", como las reclamadas por Fairfield.

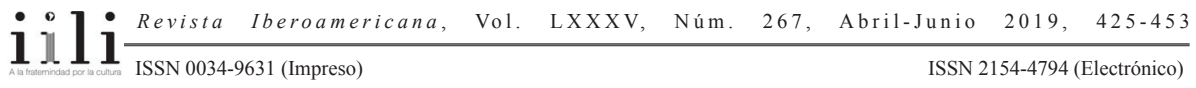


La percepción y el entendimiento de un lector de revista ilustrada del Fin de Siglo iba más allá que los de los participantes reales de los eventos, quienes probablemente no tiene ni siquiera la oportunidad de darse cuenta de lo que ocurre.

Reconociendo las limitaciones de la fotografía, en 1908, el año en el cual Caras $y$ Caretas muestra el sonido representado fotomecánicamente, con el fin de abordar críticamente un escándalo político, sus editores recurren a estructuras visuales de la década de 1880 [Fig. 18]. Estas maneras finiseculares de concebir el tiempo, el espacio y la verdad, reflejadas por un cronista como el cubano José Martí, ${ }^{8}$ parecen todavía

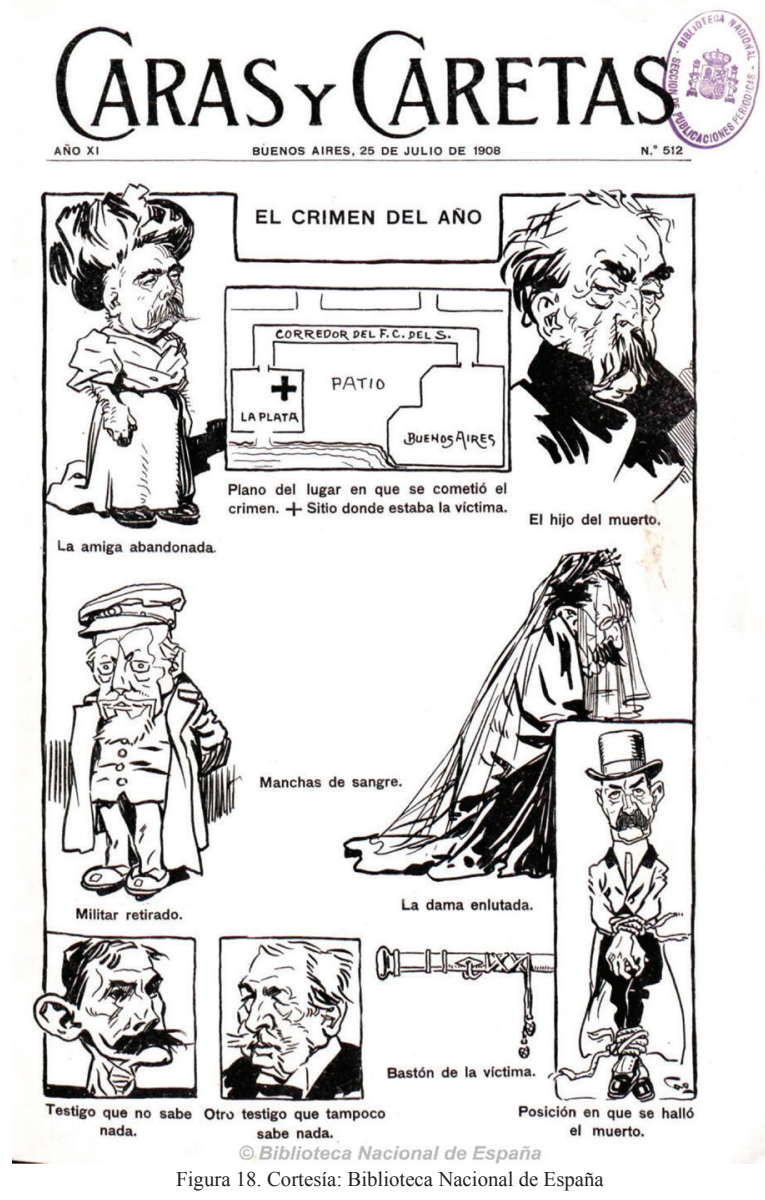

8 Para más información acerca de Martí y su relación con la prensa gráfica estadounidense, ver mi ensayo "Poetas visionarios y observadores".

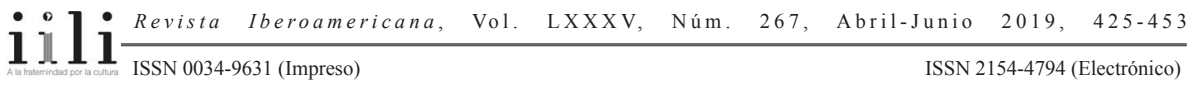


irremplazables como mecanismos para provocar percepciones virtuales complejas a principios del siglo XX; aquellas quizá sigan existiendo de manera insospechada en las visualizaciones de la percepción en el siglo XXI, enmascaradas en las maneras de ver que detonan los comics o como efectos especiales de la digitalización.

\section{BiBLIOGRAFÍA}

“An Amateur Photographer at the Zoo". The Graphic (5 setiembre 1885).

Baudelaire, Charles. El pintor de la vida moderna. Madrid: Langre, 2008.

Cerda Catalán, Alfonso. Contribución a la historia de la sátira política en el Uruguay: 1897-1904. Montevideo: Universidad de la República Oriental del Uruguay, 1965.

Fairfield, Sidney. "The Tyranny of the Pictorial". Lippincott's Monthly Magazine 55 (1895): 861-64.

Gantús, Fausta. Caricaturay poder político: crítica, censura y represión en la Ciudad de Mexico, 1876-1888. México DF: El Colegio de México; Instituto de Investigaciones Dr. José María Luis Mora, 2009.

Gretton, Thomas. "Posada and the 'Popular': Commodities and Social Constructs in Mexico before the Revolution”. Oxford Art Journal 2/17 (1994): 32-47.

"Historia de la República de Parva Domus Magna Quies". 2002.<www.enlacesuruguayos. com>. 4 mayo 2016.

Jay, Martin. "Scopic Regimes of Modernity". Vision and Visuality. Hal Foster ed. Seattle: Bay Press, 1988: 3-23.

Maturana, Carmen Luz. "La Comedia de Magia y los efectos visuales de la era precinematográfica en el siglo XIX en Chile". Aisthesis 45 (2009): 82-102.

Miller, Henry. Politics Personified: Portraiture, Caricature and Visual Culture in Britain, c. 1830-80. Manchester: Manchester University Press: 2015.

Navarro Viola, Jorge. Anuario de la prensa argentina 1896. Buenos Aires: Imprenta de P.E. Coni é hijos, 1897.

Parker, David S. “'Gentlemanly Responsibility' and 'Insults of a Woman': Dueling and the Unwritten Rules of Public Life in Uruguay, 1860-1920." Gender, Sexuality, and Power in Latin America since Independence. William E. French y Katherine Elaine Bliss, eds. Nueva York; Plymouth: Rowman \& Littlefield, 2007: 109-32.

Piccato, Pablo. "Politics and the Technology of Honor: Dueling in Turn of the Century Mexico". Journal of Social History 33/2 (1999): 331-54.

Rebaza Soraluz, Luis. "Poetas visionarios y observadores: visualidad y escritura en la modernidad hispanoamericana (1886-1954)". Escritura e imagen en Hispanoamérica: de la crónica ilustrada al cómic. Cécile Michaud, ed. Lima: Fondo Editorial de la Pontificia Universidad Católica del Perú, 2015. 203-27.

Rogers, Geraldine. Caras y Caretas: cultura, política y espectáculo en los inicios de siglo XX argentino. La Plata: Editorial de la Universidad de La Plata, 2008.

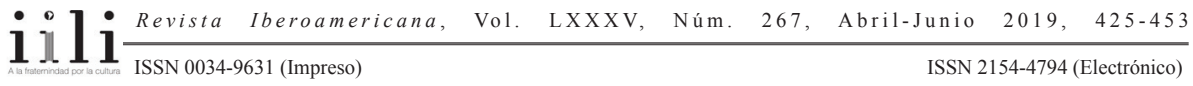


Russell Marble, Annie. “The Reign of the Spectacular”. The Dial (noviembre 1903): 297-99.

Taws, Richard. "Nineteenth-Century Revolutions and Strategies of Visual Persuasion". A History of Visual Culture: Western Civilization from the Eighteenth to the TwentyFirst Century. Jane Kromm y Susan Bakewell, eds. Oxford: Berg, 2010. 30-41.

Trévien, Claire. "The Spectacle of Science: the Art of Illusion in Prints of the French Revolution." Rupkatha Journal of Interdisciplinary Studies in Humanities 1/ 3 (2011): 42-51.

Universel Réimpression de L'ancien Moniteur. Tomo 21. París: Henri Plon, 1861.

Weston, Helen. "The Politics of Visibility in Revolutionary France: Projecting on the Streets." A History of Visual Culture: Western Civilization from the Eighteenth to the Twenty-First Century. Jane Kromm y Susan Bakewell, eds. Oxford: Berg, 2010. 18-29.

Palabras clave: modernidad, construcción social de la visión, subcultura visual, representación

Recibido: $\quad$ junio 2016

Aprobado: $\quad$ septiembre 2018 
